\title{
How time shapes crime: the temporal impacts of football matches on crime ${ }^{*}$
}

\begin{abstract}
In this paper we analyze the temporal profile of crime in the urban context of Barcelona (Spain) for the period 2007-2011 using a unique micro dataset with police reported crime. Additionally, we assess the temporal effect that a leisure activity clearly bounded in time, namely the matches played by Football Club Barcelona (FCB), exert on criminal activities. We obtain a detailed time profile for the crime recorded in the city of Barcelona and the displacement effect attributable to the football matches. The latter was found to be notable in the case of thefts, criminal damage, robberies and gender violence. Instances of gender violence were more prevalent after a FCB home defeat.
\end{abstract}

Key words: Hourly data, Reported Crime, Crime Displacement, Gender Violence, Football.

JEL classification: K42, R1, L83.

Daniel Montolio (corresponding author)

University of Barcelona \& Institut d'Economia de Barcelona

Av. Diagonal, 690

08034 Barcelona (Spain)

Phone: ++ 34934021812

Fax: ++ 34934021813

e-mail : $\underline{\text { montolio@ub.edu }}$

\section{Simón Planells-Struse}

Centro Crímina - Universidad Miguel Hernández

Avda. de la Universidad s/n. Edif. Hélike, 03201 Elche (Spain)

e-mail: s.planells@ crimina.es

\footnotetext{
* We would like to thank the Catalan police, Mossos d'Esquadra, for giving us access to the dataset and providing us with very helpful comments and insights regarding the data; and Mr. Sergi Sansano for his excellent research assistance and tireless support in the geocoding process. Daniel Montolio acknowledges support from grant ECO2013-41886-R from the Spanish Ministerio de Economía $y$ Competitividad. The usual disclaimer applies.
} 


\section{Highlights}

- We analyze the temporal profile of crime in a urban context.

- We precisely characterize the monthly, weekly and hourly patterns of crime.

- We assess the temporal effect of a leisure activity clearly bounded in time (football matches) on criminal activity.

- Results show a time displacement effect on crime attributable to football matches.

- Results show that gender violence is more prevalent after a Football Club Barcelona defeat. 


\section{Introduction}

Criminal behavior varies greatly according to the time of day but, while Felson and Poulsen (2003) note that monthly and seasonal cycles of crime are well-known periodicities among criminologists (see, for example, Harries, 1980), the hourly periodicity of crime is under-researched. This lack of research is surprising if we consider that several existing theoretical approaches to the understanding of illegal behavior, including routine activity theory (Cohen and Felson, 1979), stress the essential role of hourly activities and their association with crime opportunities (see Felson, 2002). A possible explanation for this absence of formal study of the temporal patterns of crime is because spatial patterns have tended to focus all the research attention. Indeed, the tools developed by geographers have been widely used in the spatial mapping of criminal activity and for the statistical description of spatial processes, leaving the temporal element in a secondary plane.

This predominance of the spatial perspective of crime is also linked to the "urban nature" of crime (Glaeser et al., 1996) or, in other words, how to explain that crime is too variable across space to be explained only by individual preferences, endowments or incentives. ${ }^{1}$ Social interactions (or local peer-effects) emerge as a powerful explanation of observed crime rates and provide enough variation across space (and even time) to explain why otherwise identical locations show very different crime rates. Social interactions are directly related to density and, hence, the urban context has been taken as the basic set up to analyze the empirical side of the economics of crime literature. In this sense, this paper focuses on an set-up, football matches, where social interactions (due to agglomeration and/or emotions) can be seen as prominent and also deals with an issue that lies at the core of the discussion of the future of cities in developed countries; that is, the location of big events in central cities that report prosperity but also temporarily increases in contagion, congestion and crime.

Despite the predominance of spatial issues, time would seem to play an important role in its own right in defining illegal activities. For instance, time defines when people

\footnotetext{
${ }^{1}$ This paper fits the economics of crime literature, from the urban perspective presented by O'Flaherty and Sethi (2015), in the sense that our results can be easily framed in the (strong) claim of criminogenic characteristics of offenders such as age or gender (given the specific profile of football fans); also in the evidence relating incentives faced by offenders in a situation with an remarkable increase in the number of potential victims and, hence, of the potential gains form the illegal activity; and, finally, from the view that our set up is an ideal case dealing with the creation of intense interactions related to football emotions.
} 
stumble out of bars, when alcohol or other stupefacients are consumed (concentrating around bar closing times), when drink driving tests are performed by police patrols or when the working day begins and ends. All these events can affect the number of potential offenders, the number of suitable targets and the presence (or otherwise) of police forces and, therefore, in line with routine activity theory, they have a direct impact on criminal activities.

The impact of time on crime, however, can be a priori positive or negative. On the one hand, a positive impact can be expected, given that at certain times of day crime is more likely to occur because of the routines and activities that are being engaged in (work, leisure, etc.). On the other hand, activities that are clearly demarcated by time may have a displacement effect and, hence, a negative effect on crime. In this respect, crime displacement may be defined as the relocation of crime from a particular time, place, target, offense, or tactic to another as a result of some activity and/or crime prevention initiative. Spatial displacement is by far the most commonly recognized form, but the other forms are also frequently acknowledged by researchers as they examine the impact of crime prevention policies. Clearly, it is crucial to have a good comprehensive understanding of all of possible forms of displacement so that the police forces might define prevention initiatives to tackle criminal activities.

The aim of this paper therefore is twofold. On the one hand, and drawing on a unique dataset, we analyze the temporal profile of urban crime in Barcelona (Spain) in an attempt at obtaining further evidence of monthly, weekly and hourly patterns of crime. We undertake an in-depth examination of the temporal nature of crime by determining if there is a temporal displacement of crime attributable to major events in the city of Barcelona, more specifically in relation to the matches played by Football Club Barcelona (FCB, hereafter). ${ }^{2}$ The social importance of football in Spanish society makes it an ideal event for determining whether the sport is responsible for a temporal displacement of crime in the city. Football matches, major sporting events that attract a large proportion of the population, provide excellent scenarios for analyzing temporal displacement, given that for certain periods of time (before, during and after the match) the feelings and attitudes of individuals are subject to fluctuation. Such a differentiated time profile is, therefore, optimal for analyzing the potential temporal effects on crime.

\footnotetext{
${ }^{2}$ This papers also relates, and may help to refine, the economic literature that finds a common empirical result regarding sports stadiums: stadiums have a positive impact on the desirability of its location, basically through inflating sale and rent prices (see, among others, Ahlfeldt and Kavetsos, 2013).
} 
Moreover, given the media coverage dedicated to football, these effects are not necessarily spatially constrained and, so, football matches are ideal for analyzing temporal displacement effects in criminal activities, and should further our understanding of the relationship between crime and time. The results of this analysis should provide interesting insights into the impact of football on crime, a particularly relevant issue today for governments concerned with the security issues related to major sporting events, among others. ${ }^{3}$

The rest of the paper is structured as follows. Section 2 briefly presents the various temporal patterns presented by crime data by reporting a descriptive analysis of crime on a monthly, weekly and hourly basis. Section 3 analyses the potential channels through which football matches may affect criminal activity. Section 4 describes the unique dataset on recorded crime for the city of Barcelona and outlines the methodology employed. Section 5 presents the main results regarding the temporal effect of football on crime while Section 6 presents the results for the case of defeats and violent crimes. Section 7 discusses the main results. Finally, section 8 concludes.

\section{Temporal crime patterns: a descriptive analysis for the city of Barcelona}

This section analyzes monthly, weekly and hourly crime patterns for the following crime types: property crimes (Robberies, Thefts and Criminal damage), crimes against the person (Violent crimes and Gender violence) and other crimes (Against police, Driving crimes and Drug related crimes).$^{4}$

Figure 1 (panels a to h) gives us a broad temporal picture of the evolution of the sum of offenses, by month, for each type of crime. Several features are worth highlighting. First, all types of crime, with the exception of Robberies (which presents an upward trend) and Gender violence (which presents a downward trend), are quite stable within the period of study (January 2007 - December 2011). Without seeking to be exhaustive, a priori, the reduction in the number of family related crimes (Gender violence) could be related, on the one hand, to the resources devoted by governments (national, regional

\footnotetext{
${ }^{3}$ See, for instance, Marie (2010) or the latest episodes of violence that have occurred in and around Spain's football grounds (http://deportes.elpais.com/tag/operacion_neptuno/a/ last accessed July 2016).

${ }^{4}$ See Section 4 for more details on the data used and Table 1 for a precise definition of each type of crime used.
} 
and local) to tackling this problem in Spanish society ${ }^{5}$ and, on the other, to the impact that an economic crisis can have on report rates for this type of crime.

As expected, there seems to be a marked seasonal effect with an increase in Violent crimes and, especially, Thefts in the summer. This would appear to be associated with the massive arrival of tourists - attractive targets for pickpockets - to the city during these months. ${ }^{6}$

It should perhaps be pointed out that the sharp rise in Driving crimes recorded from the end of the year 2007 reflects the new traffic regulations (Ley Orgánica 15/2007) passed on the $30^{\text {th }}$ of November, ${ }^{7}$ which increased the severity of such crimes and hence the number of offences (see BOE, 2007).

\section{$<$ INSERT FIGURE $1>$}

Figure 2 (panels a to h) presents the weekly trend for each type of crime. The daily number of crimes of each type has been calculated by taking the average of all daily crime counts for the period of study (2007-2011). For all types of crimes there is a weekend effect with crime rates increasing significantly during the weekend. ${ }^{8}$

\section{$<$ INSERT FIGURE $2>$}

In general, rates fall from Sunday to Tuesday/Wednesday; thereafter, they begin to rise again reaching a peak on Saturday/Sunday. Note the low level of reports made for drug consumption and trafficking on Sundays (a crime that peaks on Fridays), a pattern that might reflect the incapacitation of drug users by Sunday (i.e., drug consumption is highest on Fridays and Saturdays, with users resting on Sundays before the start of the week).

Finally, Figure 3 (panels a to h) shows the hourly patterns of crime. We compute the average number of crimes (by type) for every hour of the day. ${ }^{9}$ Various patterns emerge.

\footnotetext{
${ }^{5}$ Counselling, social housing, rapid police responses to aggressions and faster trials of offenders are some of the policies that have been adopted in recent years in Spain to tackle this problem.

${ }^{6}$ Tourists are known to carry valuable items on their person, including cameras and cell phones. This, together with a low level of surveillance, makes them attractive targets for offenders. See Montolio and Planells-Struse (2013) for an analysis of the impact of tourism on crime for the Spanish case.

${ }^{7}$ The law actually came into effect on 2 nd of December.

${ }^{8}$ The marked weekend effect observed for Gender violence has also been reported in Vazquez et al. (2005) and Gantz et al. (2006).

${ }^{9}$ The vertical lines plotted in all the panels of Figure 3 denote the typical kick off and final whistle times for FCB football matches (20:00 and 22:00); see footnote 12 for more details. Additionally, and given its utility for the subsequent analysis, Figure 3 plots the unconditional means for hourly evolution of crime for days when no matches were played (No game) and for days when FCB played at home (Home game)
} 
Robberies (panel 3a) and Thefts (panel 3b) present similar profiles: both peak at 19:00 (when people leave work on working days) following an upturn after 15:00. In both cases, rates are lowest around 9:00, increasing up to 13:00 and falling during lunch time (13:00-15:00). Criminal damage committed against the property of others (panel 3c) also peaks at 19:00 and is concentrated in the evening hours while during the rest of the day there is little fluctuation in the rate.

Panel 3e shows the evolution of Gender violence, with rates peaking in the late evening (having gradually increased throughout the day) and dropping off at night. Violent crimes (panel 3d) follows a similar pattern with an increasing rate from the early morning to a peak at around 19.00, but a second peak emerges at around 04:00 in the early morning. This is presumably associated with activities in leisure areas that end up in brawls and fights which, if reported to police, are likely to be catalogued as violent crimes.

In the case of the other types of illegal activity, crimes Against police (panel 3f) peaks at night $(00.00-03.00)$, again presumably related with the attempts of police forces to actively control leisure activities, which are likely to result in illegal behavior. This seems to be confirmed by Driving crimes (panel 3g) and Drug related crimes (panel 3h), which present very similar time profiles, although the latter presents a second peak between 19:00 and 20:00 (after working hours).

\section{< INSERT FIGURE 3 >}

Interestingly, the hourly evolution of the eight typologies of crime analyzed above can be broadly summarized in three time patterns: first, crimes related to leisure activities (crimes Against police, Driving crimes and Drug related crimes), with peaks late at night, low rates during the day-time and rates that increase as the evening progresses; second, crimes against property (Robberies, Thefts and Criminal damage), with low rates at night and a clear peak around 18:00 (related to the time when people are leaving work on weekdays); and, third, crimes involving violence (Violent crimes and Gender violence), with rates that increase throughout the day, peaking in the evenings. The crime types that might benefit from the hours of darkness (drug related

and when the club played away (Away game); hence, in Figure 3 we are not conditioning on any factor that can also influence hourly crime rates such as the fact that the majority of games are played on Saturday-night. In the empirical part of the paper we control, precisely, on all those potential confounding factors to isolate the impact of football games on delinquency in the city of Barcelona. 
crimes, violent crimes and criminal damage) occur more frequently during the evening, as corroborated by Calandrillo and Buehler (2008).

\section{Football, time and crime}

Having described the temporal profile of crime in the city of Barcelona and having shown that crime varies markedly with time, we now explore whether some activities might displace illegal activities in time. Barcelona is a busy city offering a wide range of cultural and tourist activities (not to mention those organized by the city's neighborhood associations), which can be examined in order to detect the existence of any kind of relationship between the timing of these activities and criminal activity. Barcelona, moreover, has a long tradition in hosting leading sporting events, commencing in 1992 with the Olympic Games and more recently with the organization of numerous World and European Championships, including swimming (2003 and 2013), athletics (2010), basketball (2014) and handball (2013). ${ }^{10}$ And, of course, Barcelona, as home to FCB and RCD Espanyol, plays host to football matches on a regular basis. ${ }^{11}$

Despite the positive economic effects that hosting a world-wide famous football club undoubtedly has for the city of Barcelona (for a cross-country comparison, see, Sterken, 2006, and Allmers and Maening, 2009), a number of negative externalities arise from its being home to such a major team and its hosting of such large events on a regular basis. ${ }^{12}$ The literature dealing with the impact of sport on crime has mainly focused on the spatial patterns of this relationship (see, for instance, Kurland et al., 2013; Rees and Schnepel, 2009; Russell, 2004; Marie, 2010; Breetzke and Cohn, 2013; Breetzke and Carl, 2009), while only a few studies have focused on the possible temporal displacement effects of such events (Card and Dahl, 2011; Doleac and Sanders, 2012; Kirk, 2008; Sachs and Chu, 2000). As such, this paper, rather than addressing the so-called crime pattern theory (Eck et al., 2007), which states that certain

\footnotetext{
${ }^{10}$ Barcelona is also the frequent host of many Spanish Championships in a variety of disciplines.

${ }^{11}$ RCD Espanyol attracts less support than FCB. By way of illustration, RDC Espanyol has 27,000 members (paying an annual fee) and around 70,000 followers on Facebook, while FCB has 169,000 members and more than 45 million followers on Facebook. Moreover, although originally with its home ground in Barcelona, RCD Espanyol moved to the neighbouring city of Cornellà-El Prat in September 2009. Therefore, for the purposes of this study we focus only on the temporal impact FCB matches have on criminal behaviour in the city of Barcelona.

${ }^{12}$ Given that FCB typically gets to the final rounds of most of the competitions that it enters means that in some periods of the season, the club is playing almost every three days (taking into account both home and away matches).
} 
specific places (such as football stadiums) are rich in suitable targets and attract potential offenders, focuses on the temporal displacement effects of football matches.

In order to provide an initial, visual evaluation of the potential temporal displacement effect of FCB matches on crime, in Figure 3 we depict the unconditional hourly crime evolution in Barcelona on days when FCB played at home and away as well as on days when FCB were not involved in a game. ${ }^{13}$ In general, the hourly patterns of crime on the three types of day are fairly similar; however, closer inspection reveals some interesting features.

In general, home match days and away match days do not differ considerably from other non football days except in the time band following the final whistle. In the case of Robberies, Thefts, Violent crimes, Gender violence, and crimes Against police officers there is an increase in the number of illegal activities in the hours after the football (both for home and away games). The same is true for Driving crimes, but in this case five to six hours after the match has finished. For Criminal damage, there are no apparent differences across the different types of day analyzed, while there is a lower level of Drug related crimes in the hours following home matches.

Certain characteristics of the days under analysis provide us with plausible explanations for the crime patterns observed. For instance, police deployment when FCB are playing at home to guarantee the protection of those going to the stadium or congregating in recreational areas to watch the match may be responsible for the marked increase observed in crimes Against police officers on home match days (given the greater interaction between fans and police officers), a decrease in Drug related crimes as the police are concerned with other security issues, and also the time profile of Driving crimes with traffic checkpoints being set up after matches.

Fluctuations in supporters' emotions following a defeat or victory may account in part for the sharp increase in Violent crimes, the rate of which also increases in the hours prior to a match. The same post-match pattern is observed for Robberies and, albeit to a lesser extent, for Thefts, which in the case of the city of Barcelona are limited mainly to pick pocketing. Incidents of Gender violence also seem to rise on match days, but the graphical evidence here is less conclusive.

\footnotetext{
${ }^{13}$ Note that FCB matches kick off at different times, depending on the match and on the competition. For instance Champions League matches always kick-off at 20:45 (CET), however, Domestic League matches may vary, the average starting time being 20:20 (and the mode 20:35). In Figure 3, therefore, the additional vertical lines correspond to an "average" 20:00 starting time and "average" 22:00 final whistle.
} 
Clearly the preceding has been an attempt at providing a descriptive approximation of the evolution of crime over time, and the possible effects that a major sporting event can have on illegal behavior. In the next section, we address the issue by means of formal estimations taking into account other possible determinants of the differences observed (day of the week, type of match, weather conditions, etc.) in crime patterns across football and non-football days.

\section{Data and empirical methodology}

\subsection{Crime data}

In this section we formally describe our unique data (used in the previous sections to describe the time patterns of crime). We use a non-public dataset for the city of Barcelona containing all registered crimes obtained from the autonomous police agency in Catalonia (Spanish region in which Barcelona is located), the Mossos d'Esquadra, which is responsible for crime prevention, crime solving and specialized crime investigation in the Catalan region. ${ }^{14}$ The dataset contains reports made both by citizens and police officers. Additionally, the dataset contains information on all the crimes registered by Barcelona's local police (the Guardia Urbana), responsible primarily for urban traffic and upholding municipal laws and ordinances.

The crime dataset records the time of the crime (when known) and the exact location. The dataset spans from 2007 to 2011 and is classified according to the more than 190 articles making up the Spanish penal code. ${ }^{15}$ In order to reduce the number of categories without creating an aggregation bias (Cherry and List, 2002) that could reduce the effectiveness of our estimations, we combined some of these articles according to the type of crime, paying particular attention not to aggregate crimes with different offender motivations (for example, crimes against the person and crimes against property). Table 1 specifies the type of crime included in each category.

For the main property crimes, we include Robberies, i.e., the use of violence in the misappropriation of the belongings of others, as opposed to Thefts, which do not involve any violence. Among property crimes, we also include Criminal damage which accounts for any type of damage caused to the belongings of others. Aggregated

\footnotetext{
${ }^{14}$ The Mossos d'Esquadra are responsible for virtually all police duties. The Spanish National Police (Cuerpo Nacional de Policía) and the military police (Guardia Civil) retain a number of administrative responsibilities (e.g., issuing of identity cards and passports) and undertake counter-terrorist and antimafia activities.

${ }^{15}$ The Mossos d'Esquadra were fully deployed in the city of Barcelona in 2006.
} 
categories of property crime often include this type of crime but the motivation that may lead an offender to commit a theft or criminal damage are clearly different.

Among violent, interpersonal crimes we include the category Gender violence, which refers to crimes committed against a family member, and Violent crimes, which includes the inflicting of injuries of any type against another person or persons. This category also includes fights that break out among crowds in places of leisure (such as night clubs or discos) or at major events (such as football matches).

\section{$<$ INSERT TABLE $1>$}

Finally, we create a separate category (Other crimes) to account for special types of crime normally reported by police officers and not by citizens. Broadly speaking, this means that if the police are not concerned with these crimes, they tend to go unreported and so are not accounted for in the registered crime data. In this category we include crimes Against police, i.e., misconduct (normally reported by the police themselves), such as, disobeying police orders or injuring a police officer; Driving crimes, i.e., driving under the influence of drugs or alcohol or traffic violations that endanger the lives of others; and, finally, Drug related crimes, i.e., crimes related to drug trafficking and/or consumption.

Table 2 shows the main descriptive statistics of the crime types used in this study. It is evident that property crimes are much more common than other types of crime. The most common offence committed in the city of Barcelona is that of Thefts, primarily pick pocketing, with a daily average of 306.79 recorded instances (nearly ten times greater than Robberies and Criminal damage). Fewer crimes against the person are recorded, although the figures for Gender violence are worrying given their implications. Finally, Driving crimes are the most common crime type among those directly recorded by police officers.

\section{$<$ INSERT TABLE $2>$}

In order to control the size of our analysis, and given that our focus is on the temporality of crime, we have opted not to include crimes such as Burglary (illegal entry into a building for the purposes of committing an offence) and Car theft. Note that all the crime types included in Table 1 are characterized by the fact that the timing of 
the offence can be quite accurately determined, either because they directly involve victims and offenders or because they are reported by police officers. In contrast, just when exactly a Burglary or a Car theft occurred is usually unknown, and has to be approximated by police officers (or victims) when filing the complaint. Moreover, police officers usually state a time window for when the crime is likely to have occurred. Therefore, so as not to distort the main aim of the study - namely, the time analysis of crime and the possible (hourly) displacement effect of football matches, we do not include these crimes.

\subsection{Football data}

We merge the above hourly crime dataset with the dataset containing all the football matches played by FCB between the $25^{\text {th }}$ of September 2007 and the $31^{\text {st }}$ of December 2011. The latter contains information regarding the day, the exact time of the match, the rival, the match result, the number of spectators and whether it was played at home or away match. Table 3 summarizes the number of matches by level of attendance and by type of match. It shows that the level of attendance was high for home matches, with $70 \%$ attracting more than 60,000 spectators to the stadium and just seven presenting an attendance of less than 40,000 spectators.

\section{$<$ INSERT TABLE $3>$}

Our dataset contains a total of 125 home and 130 away matches. Most of the matches were played in the Spanish domestic league (169). The Spanish King's Cup is the second most important domestic competition (32 matches played); however, the European Champions League is the competition that attracts by far the most spectators (50 matches played). Table 4 completes the description of the datasets used in this paper presenting the main types of crimes by match day type (no match, home match and away match).

\section{$<$ INSERT TABLE $4>$}

\subsection{Empirical methodology}

The evidence presented above seems to indicate a clear crime time profile and that a major event, such as a football match, can influence criminal behavior, especially after 
the event. In order to study the temporal behavior of crime and potentially distinct patterns on match days, we use a panel approach comprising two time dimensions: time of day and days. Thus, we compare the same times on different days while controlling for any potential source of heterogeneity across days, weeks, months and years. The empirical model used is the following:

$$
\operatorname{Crime}_{d, h}^{k}=\operatorname{Match}_{d, h}^{t} \sum_{l=-7}^{7} \delta_{d, h+l}+\beta X_{d}+\gamma_{y}+\gamma_{m}+\gamma_{w}+\sum_{c=1}^{3} \gamma_{d}^{c}+\gamma_{h}+\varepsilon_{d, h}
$$

where $k$ denotes the type of crime, $d$ denotes the day in our time span running from the $25^{\text {th }}$ September 2007 to $31^{\text {st }}$ December 2011 and $h$ is the time of day from 00:00 to 23:00. $t$ denotes the type of match played (home or away) ${ }^{16}$ thus, the variable Match $_{d, h}^{t}$ can be transformed into Home $e_{, h}$ and Away $_{d, h}$, which are dummy variables taking a value of 1 if it is a time when there is a home or an away match being played, respectively, and 0 otherwise. ${ }^{17}$ The subscript $l$ denotes the lag and lead effects of home and away matches. We analyze a period of up to seven hours before and after the match, assuming this to be a reasonable time period to observe the displacement effect of football on crime rates.

In Eq. (1) $X_{d}$ represents a vector of control variables that can affect (recorded) crime, such as weather variables (average rainfall, average number of sun hours, average temperature, average pressure, average wind speed). ${ }^{18}$ The weather has long been recognized to be an important factor influencing crime dynamics. For instance, higher temperatures can explain, through a psychological effect, higher levels of violent crimes (Anderson, 2001; Harries et al., 1980; Jacob et al., 2004). Rain has also been shown to be a determinant in explaining lower levels of violent crime, perhaps due to the lack of social interactions among individuals (people are more likely to stay at home and not go out) or due to the lack of potential targets. We also include a dummy variable accounting for the lunar phase (indicating the presence of the full moon) since some police agencies have reported experiencing higher levels of violent crime when there is

\footnotetext{
${ }^{16}$ We retain only those months corresponding to the football season in the sample; that is, we discard the summer months from the beginning of June to the end of August. Recall, the summer months are characterized by high seasonal crime records.

${ }^{17}$ We assume a match has a two-hour duration (90 minutes plus stoppage time).

${ }^{18}$ Weather variables present daily variation.
} 
a full moon. ${ }^{19}$ This set of control variables is completed by a dummy variable that indicates if a particular day is a bank holiday; summer and winter seasonal dummies, dummies for days (home and away) with special matches such as the big derby between historic rivals FCB and Real Madrid CF which is considered, by the police, as a potentially dangerous match, and dummies to control for the type of competition (Spanish Domestic League, European Champions League, Spanish King's Cup, Spanish Super Cup and International Super Cup) since this may determine the typology of person interested in (and following) the match.

In order to account for unobserved heterogeneity across time, days, weeks and years in our data span, we include a full set of time fixed effects. First, we include an hour of the day fixed effect $(\not h)$ since, as shown in Figure 3, those hours with the greatest movement of workers (early morning or after work) are more likely to coincide with the peak times for pick pocketing. ${ }^{20}$ By including hour of the day fixed effects, we capture this unobservable time characteristic and ensure our estimations of the effect of football matches on crime are unbiased. Second, we include three types of dummies related to different days $\left(\gamma_{d}^{c}\right)$; $(i)$ day of the week fixed effects to account for the heterogeneity of crime across days. As shown in Figure 2, there is a clear weekend effect (maybe due to higher outdoor/leisure mobility of individuals or to higher alcohol and drug consumption). By including these specific day of the week fixed effects we can capture these weekend effects as well as other specific day effects, such as, (ii) day of the month fixed effects, which account for days with specific monthly characteristics (for instance, pay day in the lasts days of a month); and (iii) day of the year fixed effects, which control for special days such as Christmas Day, New Year's Eve, local holidays (fiestas) or any other special day.

Third, a part from controlling for day of the week and for hourly fixed effects, the significant variation in Figures 2 and 3 suggests that there is most likely a day-hour specific effect. Therefore, we introduce an hour-by-weekday fixed effects (using 2-hour window)..$^{21}$

Fourth, we also include week of the year $\left(\gamma_{w}\right)$, month of the year $\left(\gamma_{m}\right)$ and annual fixed effects $\left(\gamma_{y}\right)$. Finally, we draw on monthly and yearly trends to account for potential

19 See "Crackdown on lunar-fuelled crime". BBC News. 5 June 2007 at http://news.bbc.co.uk/2/hi/uk_news/england/kent/6723911.stm (last accessed July 2016).

${ }^{20}$ All the temporal fixed effects and trends included in the regressions have been based on the descriptive temporal crime analysis carried out in the previous section.

${ }^{21}$ We have computed (but not reported) all the results tables using a 3-hour window obtaining consistent estimates, very similar to those finally reported. 
trends (e.g., thefts increase from the beginning of the year to the end of August) or for different levels of popularity expressed for FCB (e.g., the club may be more popular one year because it won a major title the previous season or because it bought a world-class player).

As we employ hourly data, the crime count in our dataset is positively skewed with a large presence of zeros. Taking logs would result in a considerable increase in the number of missing values, which could bias our estimations. In order to deal with data of this type, we follow Marie (2010) and Dahl and DellaVigna (2009) and use a negative binomial approach. Such estimations constitute a generalization of the Poisson model but allow for the over dispersion of data, in other words, they allow for the variance of the outcome to differ from the mean.

\section{Main results}

In this section we present the results of estimating Eq. (1), that is, the temporal effect of football on crime. The columns of each table of results present the different crime types considered. All the regressions include the full set of controls previously presented. Note that given that we estimate a negative binomial model, the coefficients reported are the incidence rate ratios that represent the increase or decrease in percentage of the number of counts of each crime type.

Table 5 shows the results of the impact of FCB playing at home on crime, focusing on the time when the games are played (recall, we consider a game to have a duration of two hours). ${ }^{22}$ Note that using the hour-by-weekday fixed effects (using a 2-hour window) make the estimations very demanding in terms of statistical significance given that we compare the same time window on the same weekday, with and without FCB games. $^{23}$ The first row represents the impact of an increase of 10,000 spectators on the different types of crime. Although the results are not statistically significant, to interpret the incidence ratios reported, and for the case of Robberies, the coefficient presents a decrease in the expected number of Robberies of $0.3 \%$ (1-0.997) during the football match for each 10,000 additional spectators in the stadium.

\footnotetext{
${ }^{22}$ Note that we have computed the two hour length for each game from the exact time that the game started.

${ }^{23}$ Relaxing the hour-by-weekday fixed effects we obtain qualitatively similar results than those reported but, as expected, with lower p-values and, hence, better results in terms of significance of the estimated parameters.
} 


\section{$<$ INSERT TABLE $5>$}

Similarly, the following rows analyze the effect of different matches depending on attendance. In general, it seems that football matches only have a slightly significant impact on crime (for the duration of the game), in the case of those attended by over 60,000 spectators. These matches are typically important games for FCB. During such matches, there is an increase in the number of Robberies in the city, and there is some weak evidence of a reduction in crimes Against police (especially for matches with more than 80,000 spectators) during the two hours of the game. This lack of significant results for crime during the time of the match (or even the reductions in some crime types) might point to an incapacitation effect on offenders, as found by Dahl and DellaVigna (2009) in relation to violent movies. More precisely, as Dahl and DellaVigna (2009) show in their study of the impact of violent movies on violent crime, the size of an audience should matter more for criminal behavior if there is selfselection into attendance. Hence, and as also explained by Marie (2010), our argument is that football fans are a non-random sample of the population with demographic characteristics that make them more prone to be potential offenders. ${ }^{24}$ The detailed results for the vector of control variables $\left(X_{d}\right)$ for the above estimation are reported in Table 6.

\section{$<$ INSERT TABLE $6>$}

In general, some climate variables are related to crime behavior. For instance, longer days in terms of sun hours, warmer days in terms of temperature, calm days in terms of wind speed, and non-rainy days, are related to higher crime rates (especially property crimes).

We examine in greater depth the temporal profile of crime and the way in which football can shape it in Figure 4 by presenting the detailed results of crime in the hours leading up to and following FCB home matches. On the one hand, in the pre-match hours there seems to be fewer Driving crimes and Drug related crimes. In the case of interpersonal Violent crimes there also seems to be a reduction in the crime rate, but at a much earlier point in the day (four hours before the match). In the case of Thefts

\footnotetext{
${ }^{24}$ Note that in our case, a priori, there is a similar profile of football supporters and that of (potential) offenders: basically young males.
} 
(primarily pick pocketing, see panel 4b), in the hour immediately prior to the match, the number of thefts increases by around $28 \%$ and two hours before the increase is significant and equal to $8.7 \%$. These elasticities imply a statistically significant increase, during these two hours, of five thefts due to the football game (recall that the hourly average of Thefts in Barcelona is 12.80). Also robust is the increase found for Criminal damage one hour (18.6\%) and two hour (18.1\%) prior to kick-off.

\section{$<$ INSERT FIGURE 4 >}

In the hours following the match there seems to be a marked increase in crime. This result is, as expected, very strong and robust for Thefts. Victory celebrations bring supporters out on to the streets making them targets for thieves. The number of Thefts peaks just one hour after the match (39.9\%), but the impact of the event remains throughout the night (with incidence ratios above 1 although not always significant). Likewise, an increase in the number of Robberies (involve some sort of violence) is recorded, especially six and seven hours after the final whistle, along with more instances of Criminal damage and crimes Against police between two and three hours after the match. These results are related to post-match activities that include victory celebrations and/or going out after the match.

Table 7 and Figure 5 show the results for away matches, given that a city with a major team will have a large number of supporters that are liable to modify criminal patterns, even when the team plays away. Table 7 shows a significant reduction in Drug related crimes that could be driven by an incapacitation effect during the match. ${ }^{25}$ Table 7 also shows a significant increase in the number of recorded crimes Against police: the coefficient is positive and significant at the $1 \%$ level indicating an increase in the number of this type of crime of $57.4 \%$. This result might be attributed to the celebrations of the football fans who meet in bars or at specific locations in the city. ${ }^{26}$

\section{$<$ INSERT TABLE $7>$}

\footnotetext{
${ }^{25}$ Note that in Table 5 we include attendance at home games. If we perform a similar regression as that presented in Table 7 but with a dummy variable indicating home match we also find a reduction in the crime committed in the city during the hours of the game.

${ }^{26}$ Barcelona football fans traditionally meet at the Canaletes fountain in the city center to celebrate their victories.
} 
Figure 5 presents the time profile of crime in the hours leading up to and following FCB away matches. In this case the results seem quite clear: Thefts seem not to be affected prior to the game and increase after it (especially two hours after the game with a $17,3 \%$ increase). Some evidence of a lower level of crime prior to the game can be observed for Robberies (6 hours before) and crimes Against the police (1 hour before) both types increasing after the game, especially the latter type of crime. The opposite pattern is found for Violent crimes (with increases 2 and 3 hours before) and Driving crimes (with increases 3 hours before). In common with home games, in the hours following the match, people typically go to bars and meet with friends to celebrate or to console themselves in defeat. This can create large crowds that attract pick pockets, increase Criminal damage (including urban furniture) or, by increasing the level of social interaction, lead to higher levels of interpersonal violence.

\section{$<$ INSERT FIGURE $5>$}

In sum, the results obtained for the temporal impact of away matches on crime broadly confirm the patterns observed for home matches. The differences observed can be attributed to the spatial dimension, which has purposefully been omitted from the present analysis. Clearly, the high spatial concentration of individuals when FCB play at home is likely to be the driver for some of the results obtained during home matches and not during away matches.

\section{Results on gender violence}

Note that all the results obtained up to this point seem to indicate that football matches do not have any effect on Gender violence. However, and as reported by Card and Dahl (2011), what seems to spark family violence (and violence in general) are defeats. ${ }^{27}$ Indeed, in such instances the authors find a direct relationship between these

\footnotetext{
${ }^{27}$ The theoretical background for linking gender violence and the emotional cues associated with wins and losses in sports was provided by Card and Dahl (2011) who hypothesized that family violence can be understood as the result of a gain-loss utility of game outcomes around a rationally expected reference point. Although this rationale could be in principle applied to our paper, the empirical translation needs some refinements given that our set up does not completely fit that framework given the nature of the football team (FCB) we analyze. In this sense, we only analyze the results of one specific team; the betting market in Spain is not as developed as in other countries such as US or UK; and we expect that, by default, FCB is always considered as favorite to win each and every game, hence, with low pregame point spread. Indeed, we take advantage of losses as the unexpected result given that FCB is always considered as favorite in all games played.
} 
emotional cues and crime ${ }^{28}$ which suggests this type of crime may occur after a football match. Moreover, following Munyo and Rossi (2013) we also report, a part from specific results for Gender violence, the results for Violent crimes of an unexpected FCB result. Note that Munyo and Rossi (2013) present a very interesting natural experiment to analyze the potential causal relation between frustration and aggression applied to the Uruguayan football framework (via comparing odds in the betting market and real game results). Although Spanish football cannot be directly compared with the passion of South American football, the authors find that frustration (unexpected loss) is followed by a spike in violent crime whereas euphoria (unexpected win) is followed by a reduction in violent crime. The two effects are concentrated in a 1 hour time window after the end of the game. Here, our results (see Table 8) point to the presence of this temporal displacement effect, indicating that Gender violence is a relevant crime type to analyze from a temporal perspective. Indeed our results show a positive and significant effect of (home) defeats on Gender violence.

Thus, from between three and six hours after a home defeat, there appears to be an effect on violent behavior in a family related environment, with such crimes rising by up to 92-98\%. A similar result was reported by Card and Dahl (2011) for the case of the NFL in North America. In the case of non-family Violent crimes, there does not appear to be a consistent increase, though five hours after a home defeat an increase in the number of violent crimes is noted.

\section{$<$ INSERT TABLE $8>$}

\section{Discussion}

The results reported above regarding the temporal displacement effect of football matches on crime rates require a fuller discussion. As already mentioned, the results associated with home matches can be explained if we take into account the spatial dimension. For instance, the fact that the number of Thefts increases during the two hours before the match would seem to indicate that offenders take advantage of the agglomeration of supporters entering (or congregating near) the stadium. Although a proper spatial analysis needs to be conducted to confirm that this increase in Thefts is

\footnotetext{
${ }^{28}$ Our sample includes 25 defeats and 56 draws in total. Of these, 15 defeats and 38 draws occurred in away matches.
} 
due to the agglomeration of football fans, the fact that a similar increase does not occur before away matches provides partial confirmation.

The results obtained in the hours leading up to a home match can be accounted for in terms of a substitution effect. That is, since large numbers of police officers are deployed in order to safeguard citizen security around the stadium, less attention is given to other criminal activities (for instance, drug consumption, dangerous driving or alcohol consumption) and so crime reports fall (especially since these crimes are reported by the authorities themselves). In the case of Drug related crimes this effect also appears to last up to three hours after the game. These results again are confirmed by the apparent effect of away matches, which as expected present no impact on these types of crime, given the absence of any substitution effect.

Importantly, therefore, our estimates, after controlling for a wide range of possible temporal determinants, indicate that certain crime types increase after FCB football matches. Some of these increases can be attributed to victory celebrations or the commencement of weekend leisure activities after watching the game, accompanied by consumption of alcohol. This is the case of Robberies and Criminal damage regardless of whether FCB have played at home or away (albeit in different time spans), indicating that this impact can be attributed, in general, to the euphoria occasioned by football. Logically, crimes Against the police increase after home and away matches, attributable to agglomerations and problems of euphoric crowds clashing with police officers in the vicinity of the stadium (home matches) and in the City center (home and away matches).

\section{Conclusions}

This paper has presented the first detailed temporal analysis of crime in an urban context, with a particular focus on the hourly displacement of crime patterns attributable to the scheduling of a major sporting event (i.e., FC Barcelona's football matches). In short, we have analyzed the principal effects of these games on crime before, during and after the match.

First, as expected, the results reveal a clear time pattern for criminal activities. Although different patterns are found according to the specific type of crime under analysis, we can report a number of stylized facts. Crimes most closely associated with leisure activities (e.g., crimes Against police, Driving crimes and Drug related crimes) peak late at night, presenting low rates during the day-time which increase as the 
evening progresses. Crimes against property (Robberies, Thefts and Criminal damage) peak after 18:00 (associated with people coming out of work on weekdays), but fall again as the night progresses. Crimes involving violence (Violent crimes and Gender violence) gradually increase throughout the day and peak in the evenings. Additionally, we find evidence of a week-end effect for all crimes, while some types of crime present a marked seasonal pattern, especially those most closely associated with tourism (Violent crimes and Thefts).

Second, our results point to the temporal impact of football matches on crime rates. Thus, we find a fall in some types of crime in the hours before an FCB football match is played and an increase in some types of crime afterwards. The reduction in crime prior to a match would appear to be capturing the incapacitation effect of potential offenders, whereas the post-match increase appears to depend on the type of crime. Thus, increases in Thefts, Robberies and Criminal damage occur regardless of whether FCB have played at home or away, indicating that offenders are taking advantage of victory celebrations or the initiation of post-match leisure activities. Other significant increases appear to be related to the spatial distribution of individuals in association with the match that has just been played; thus, for instance, the increase in crimes Against police reported after FCB matches appears to point to the impact of spatial concentration on crime (around the stadium or in celebrating areas).

Our study identifies an interesting impact that is likely to be related to the possible substitution effect experienced by some types of crime and which reflects the specific deployment of police resources during a football match. In general, during major events, such as FCB matches, police officers inevitably switch their attention away from fighting certain types of crime in favor of safeguarding citizen security in and around the event. For example, police check points or random checkpoints are not manned with the subsequent fall in the number of reports of drunk driving, drug consumption or drug smuggling.

In general, football matches do not appear to have any impact on rates of Gender violence; however, an increase is noted when the sample is restricted to those games in which FCB were defeated (especially when defeated at home), and so we obtain some evidence of a link between sports results and violence in the family.

The results reported herein provide new, broader evidence on the crime patterns produced on football match days, pointing to the temporal displacement effects that football matches may have on crime. As such, it is our belief that these results can be 
useful in determining the temporal deployment of police officers on match days as well as in understanding the way in which offenders behave according to the characteristics of a match day. Further research needs to be focused on spatial analyses, which should illustrate how the crimes are spatially distributed across the city and how football matches can alter these crime patterns. Similarly, closer collaboration with police agencies should improve the data available for researchers, since knowledge of the actual allocation of police officers and their deployment during a match is essential for identifying crime displacement and concentration effects. 


\section{References}

Ahlfeldt, G. M., and Kavetsos, G. (2013). Should I wish on a stadium? Measuring the average effect on the treated. The Econometrics of Sport, 189.

Allmers, S. and Maennig, W. (2009). Economic impacts of the FIFA Soccer World Cups in France 1998, Germany 2006, and outlook for South Africa 2010. Eastern Economic Journal, 35(4), 500-519.

Anderson, C.A. (2001). Heat and Violence. Current Directions in Psychological Science: $33-38$.

Barker, M., Page, S. J. and Meyer, D. (2002). Modeling tourism crime: The 2000 America's cup. Annals of Tourism Research, 29(3), 762-782.

BOE (2007). Ley Orgánica 15/2007, de 30 de noviembre, por la que se modifica la Ley Orgánica 10/1995, de 23 de noviembre, del Código Penal en materia de seguridad vial. Boletín Oficial del Estado número 288, December 1st 2007.

Breetzke, G. and Cohn, E.G. (2013). Sporting Events and the Spatial Patterning of Crime in South Africa: Local Interpretations and International Implications. Canadian Journal of Criminology and Criminal Justice/La Revue canadienne de criminologie et de justice pénale, 55(3), 387-420.

Breetzke, G. and Carl, A. (2009). A geodemographic profiler for high offender propensity areas in the City of Tshwane, South Africa. Environment and Planning A, 41(1), 112-127.

Calandrillo, S. and Buehler, D.E. (2008). Time Well Spent: An Economic Analysis of Daylight Saving Time Legislation. Wake Forest Law Review, 45.

Card, D. and Dahl, G.B. (2011). Family Violence and Football: The Effect of Unexpected Emotional Cues on Violent Behavior. The Quarterly Journal of Economics, 126(1), 103-143.

Cohen, L.E. and Felson, M. (1979). Social change and crime rate trends: A routine activity approach. American Sociological Review, 588-608.

Cherry, T. and List, J. (2002). Aggregation bias in the economic model of crime. Economic Letters, 81-86.

Dahl, G. and DellaVigna, S. (2009). Does Movie Violence Increase Violent Crime?. Quarterly Journal of Economics, 124, 677-734.

Doleac, J. and Sanders, N. (2012). Under the Cover of Darkness: Using Daylight Saving Time to Measure How Ambient Light Influences Criminal Behavior. Stanford Institute for Economic Policy Research, Discussion Paper No. 12-004. 
Eck, J.E., Ronald V.G. Clarke and Guerette, R.T. (2007). Risky facilities: crime concentration in homogeneous sets of establishments and facilities. Imagination for Crime Prevention. Crime Prevention Studies, 21, 225-264.

Felson, M. and Poulsen, E. (2003). Simple indicators of crime by time of day. International Journal of Forecasting, 19(4), 595-601.

Felson, R. (2002). Violence and gender reexamined. Washington, DC: American Psychological Association.

Gantz, W., Bradley, S. D. and Wang, Z. (2006). Televised NFL matches, the family, and domestic violence in Handbook of Sports and Media, Raney, A. and Bryant J. (eds.), Chapter 22, 365-382.

Glaeser, E. L., Sacerdote, B., and Scheinkman, J. A. (1996). Crime and social interactions, Quarterly Journal of Economics, Vol. 111, no. 2 (May 1996): 507-548

Harries, K. D. (1980). Crime and the Environment. Thomas.

Harries, K.D., Stadler, S.J. and Zdorkowski, E. (1980). Seasonality and Assault: Explorations in Inter-Neighborhood Variation, Dallas 1980. Annals of the Association of American Geographers, 74 (4), 590-604.

Jacob, B., Lefgren, L. and Moretti, E. (2004). The dynamics of criminal behavior: evidence from weather shocks. Journal of Human Resources, 42.

Kirk, M. G. (2008). The spatio-temporal effects of spectator events on crime. Master's thesis, Simon Fraser University, Burnaby, BC.

Kurland, J., Johnson, S. D. and Tilley, N. (2013). Offenses around stadiums: A natural experiment on crime attraction and generation. Journal of research in crime and delinquency, 5(1), 5-28.

Marie, O. (2011). Football Matches: the Effects on Crime. Centre for Economic Performance Working Paper No. 348, London School of Economics.

Montolio, D. and Planells-Struse, S. (2013). Does tourism boost criminal activity? Evidence from a top touristic country, Crime \& Delinquency, DOI: $10.1177 / 0011128713505489$

Munyo, I., and Rossi, M. A. (2013). Frustration, euphoria, and violent crime. Journal of Economic Behavior \& Organization, 89, 136-142.

O'Flaherty, B., and Sethi, R. (2015). Urban crime. Handbook of Regional and Urban Economics. Edited by Gilles Duranton, J. Vernon Henderson and William C. Strange, Volume 5, 2015, Chapter 25, Pages 1519-1621.

Rees, D. I. and Schnepel, K. T. (2009). College football matches and crime. Journal of Sports Economics, 10(1), 68-87. 
Russell, G. (2004). Sport Riots: A Social-Psychological Review. Aggression and Violent Behavior, 9, 353-378.

Sachs, C. J., and Chu, L. D. (2000). The association between professional football matches and domestic violence in Los Angeles County. Journal of Interpersonal Violence, 15(11), 1192-1201.

Sterken, E. (2006). Growth impact of major sporting events. European Sport Management Quarterly, 6(4), 375-389.

Süssmuth, B., Heyne, M., and Maennig, W. (2010). Induced Civic Pride and Integration. Oxford Bulletin of Economics and Statistics, 72(2), 202-220.

Vazquez, S. P., Stohr, M. K., and Purkiss, M. (2005). Intimate partner violence incidence and characteristics: Idaho NIBRS 1995 to 2001 data. Criminal Justice Policy Review, 16(1), 99-114. 

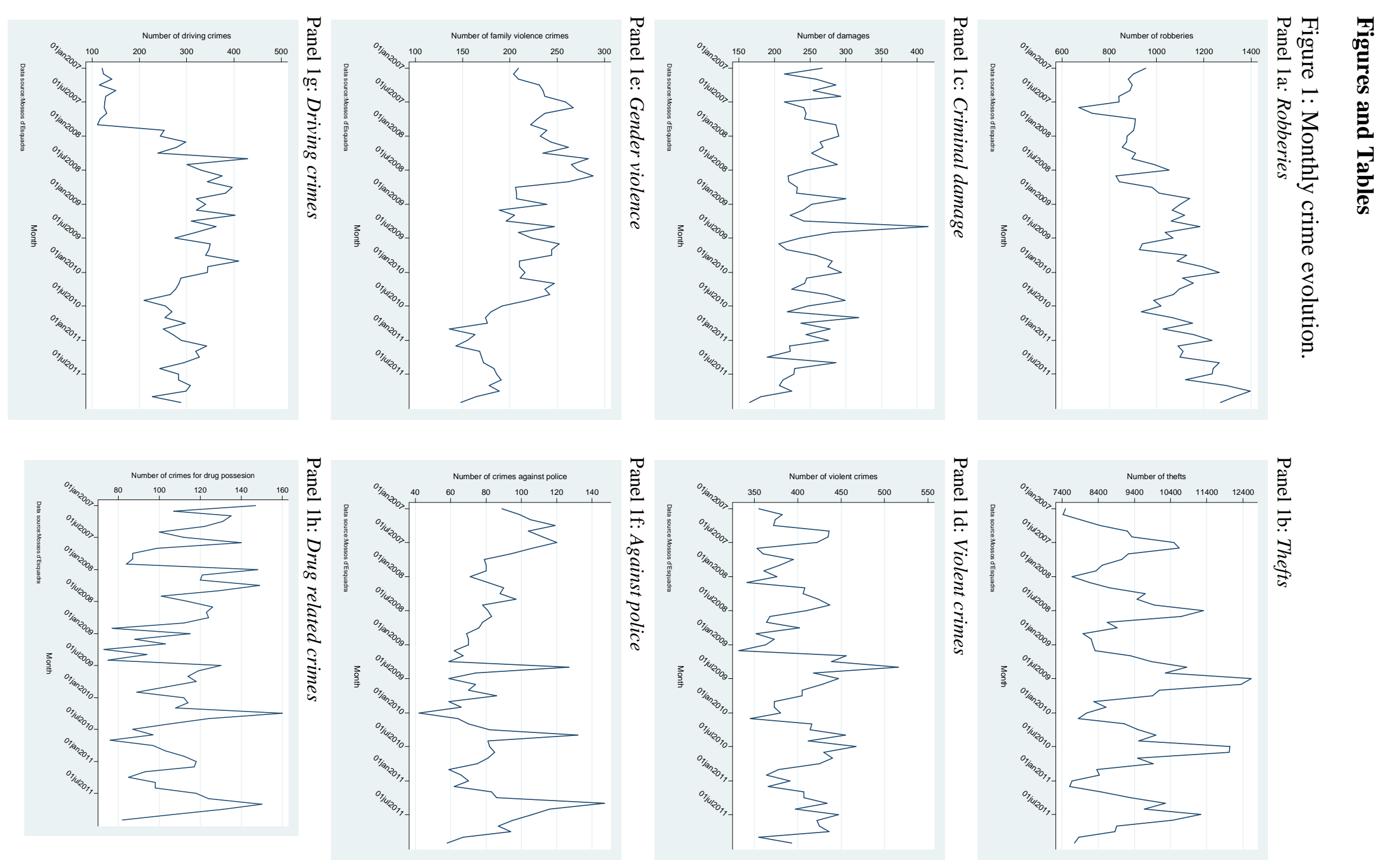
Figure 2: Weekly crime evolution.

Panel 2a: Robberies

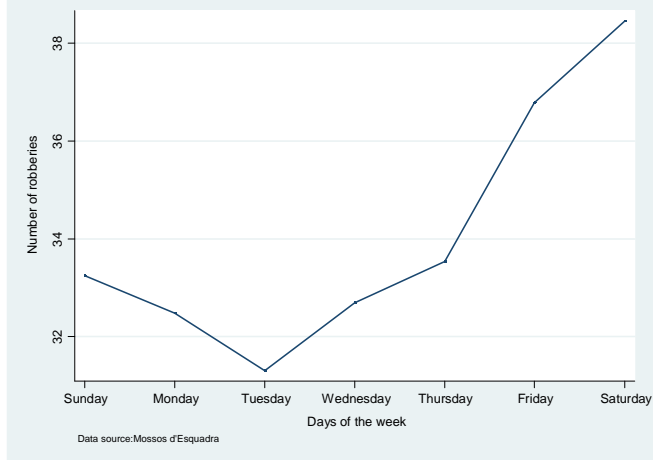

Panel 2c: Criminal damage

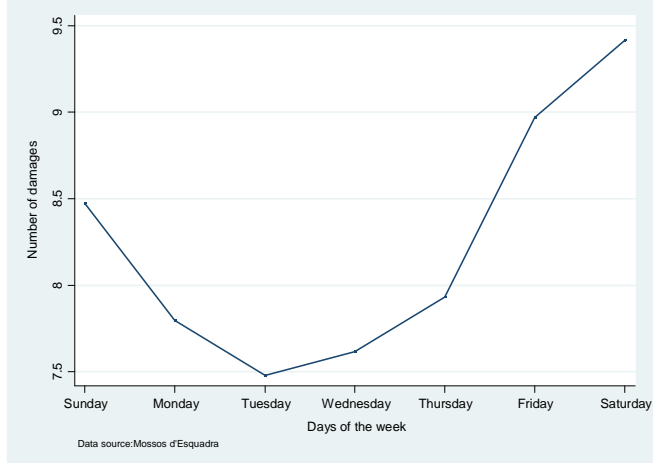

Panel 2e: Gender violence

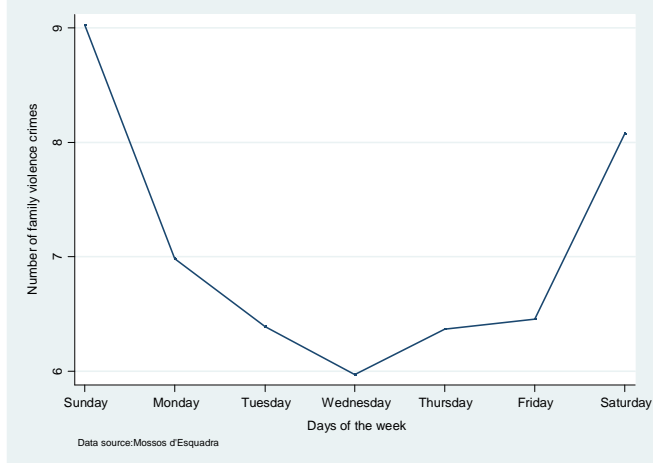

Panel 2g: Driving crimes

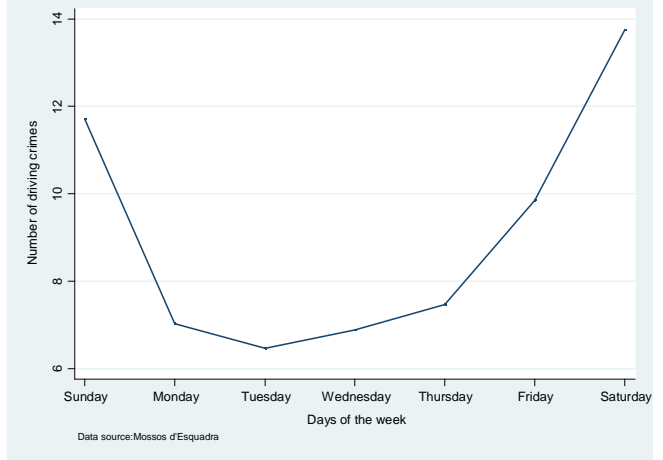

Panel 2b: Thefts

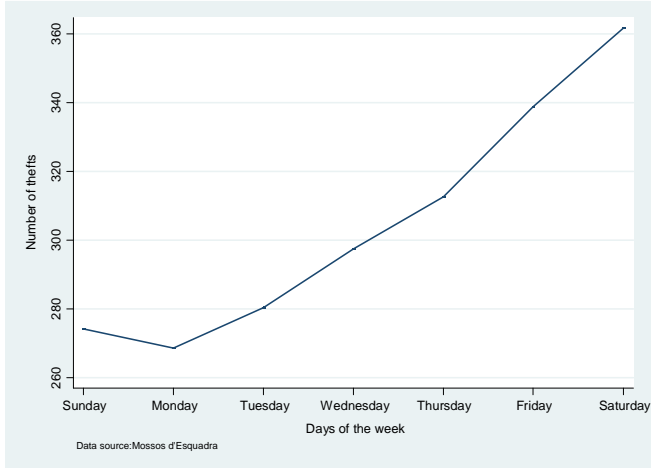

Panel 2d: Violent crimes

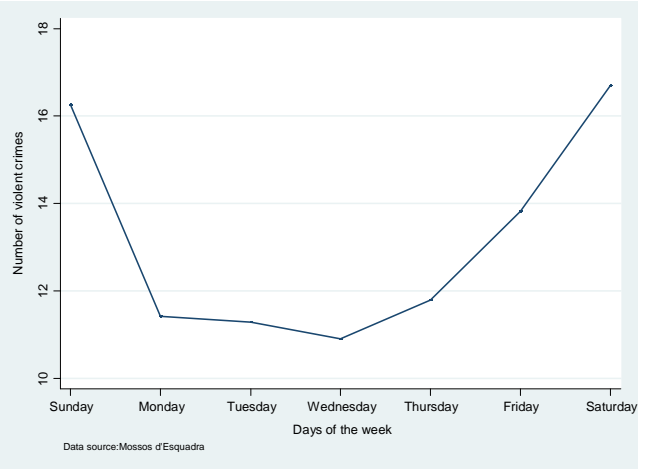

Panel 2f: Against police

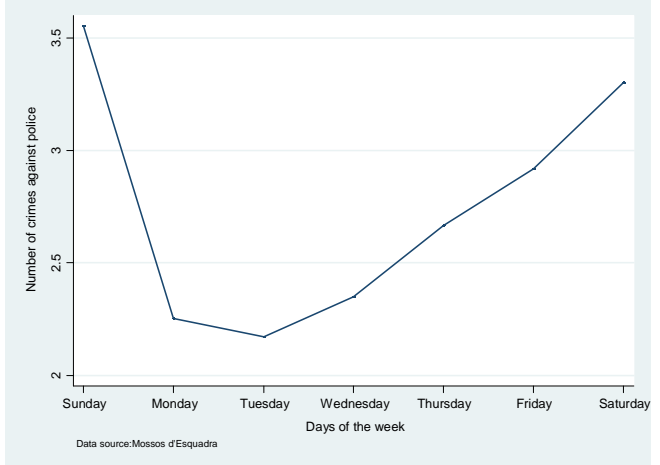

Panel 2h: Drug related crimes

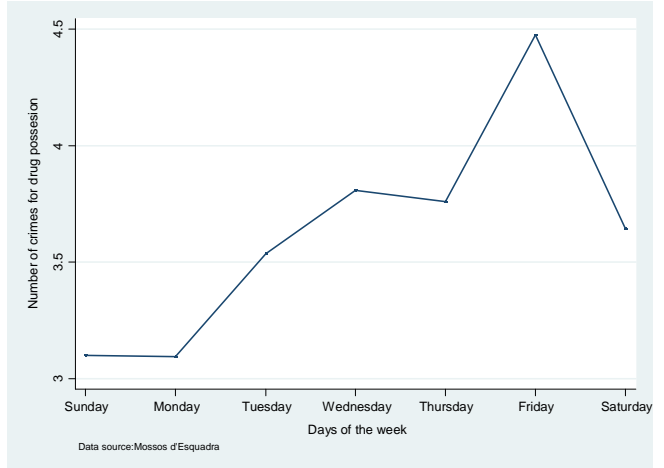


Figure 3: Hourly crime evolution.

Panel 3a: Robberies

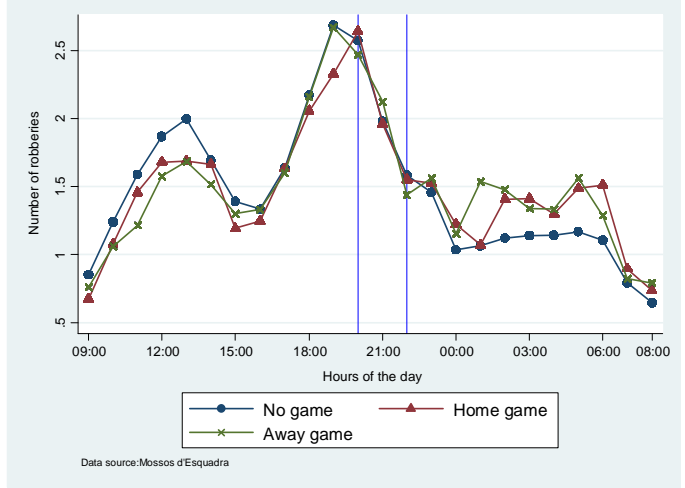

Panel 3c: Criminal damage

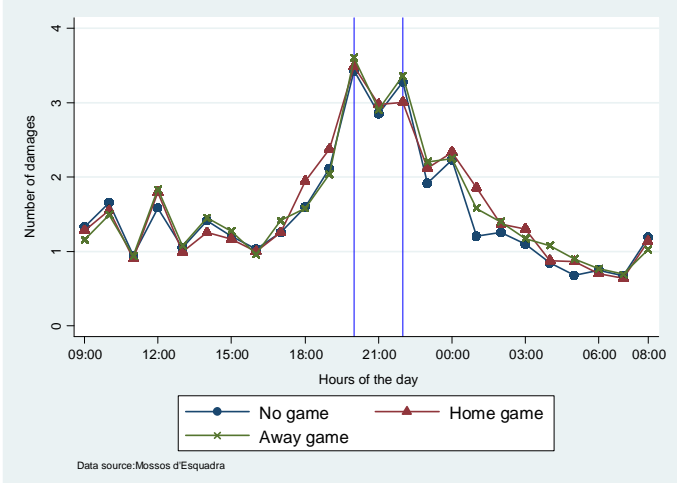

Panel 3e: Gender violence

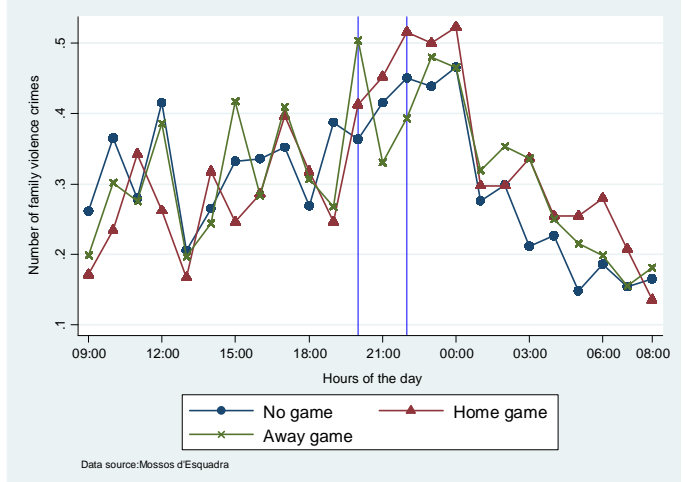

Panel 3g: Driving crimes

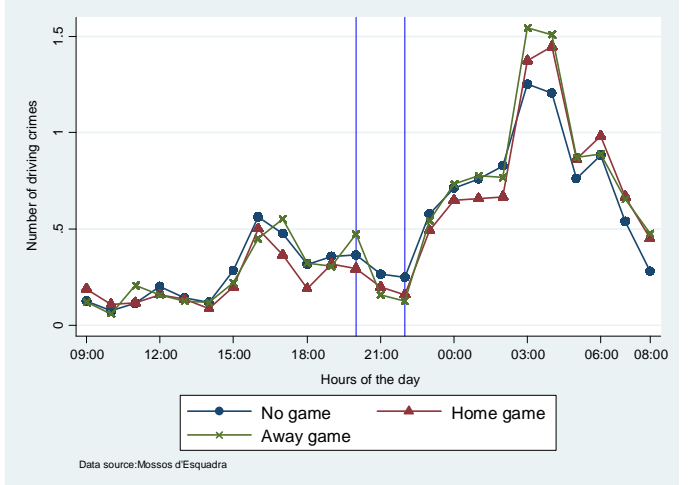

Panel 3b: Thefts

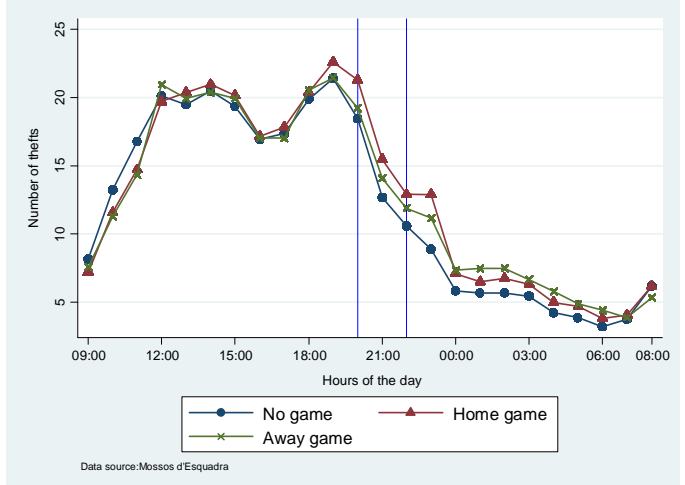

Panel 3d: Violent crimes

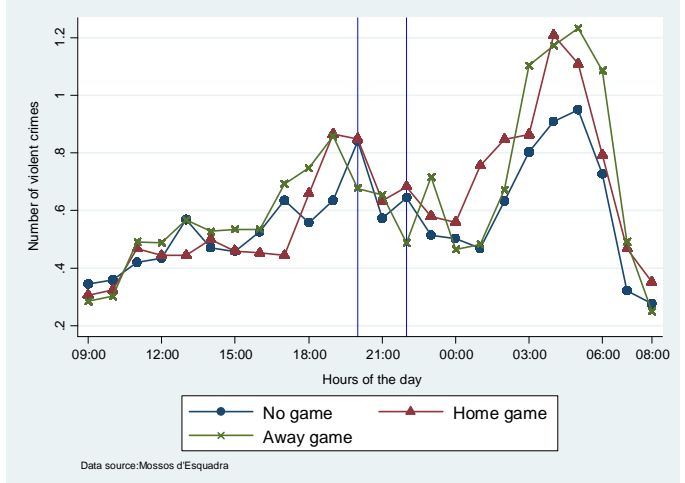

Panel 3f: Against police

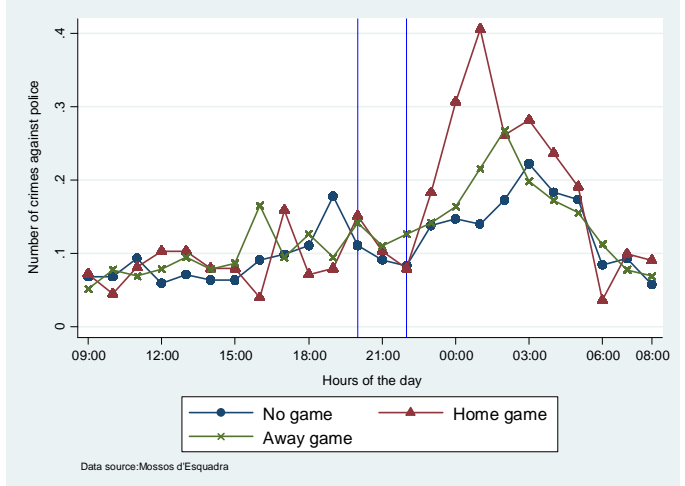

Panel 3h: Drug related crimes

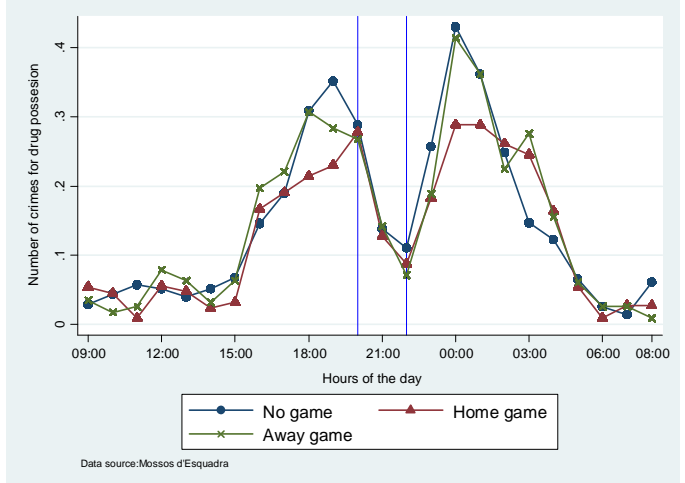


Table 1: Crime classification.

\begin{tabular}{ll}
\hline Type & Description \\
\hline $\begin{array}{l}\text { Property Crimes } \\
\text { Robberies }\end{array}$ & $\begin{array}{l}\text { Misappropriation of the belongings of others against their will with the } \\
\text { use of violence. } \\
\text { Misappropriation of the belongings of others against their will without } \\
\text { the use of any violence. }\end{array}$ \\
Criminal damage & Minor/serious damage to the belongings/property of others. \\
Crimes against the Person & $\begin{array}{l}\text { Physical injuries to other individuals. Mass fights and brawls. } \\
\text { Violent crimes }\end{array}$ \\
Aender violence & $\begin{array}{l}\text { Abuse in the home. Physical and psychological violence in the home. } \\
\text { Other Crimes }\end{array}$ \\
Against police & $\begin{array}{l}\text { Misconduct, intimidation, resistance, use of force and aggressions } \\
\text { against police officers. } \\
\text { Dangerous driving. Driving with no license. Driving under the influence } \\
\text { of alcohol or drugs (considered a serious crime when alcohol tests are } \\
\text { above a certain threshold). Endanger lives of other drivers. } \\
\text { Drug consumption in public areas and drug trafficking. The amount of } \\
\text { drugs determines the classification. }\end{array}$ \\
Driving crimes &
\end{tabular}


Table 2: Average number of crimes by different time dimensions.

\begin{tabular}{lcccc}
\hline Type & Hour & Day & Month & Year \\
\hline Property Crimes & & & & \\
& 1.46 & 34.96 & $1,064.39$ & $11,069.6$ \\
Robberies & $(1.43)$ & $(8.73)$ & $(144.44)$ & $(4,430.41)$ \\
& 12.80 & 306.79 & $9,339.25$ & $97,128.2$ \\
Thefts & $(8.58)$ & $(61.57)$ & $(1,273.94)$ & $(34,918.44)$ \\
& 1.50 & 35.96 & $1,094.69$ & $11,384.8$ \\
Criminal damage & $(1.55)$ & $(9.84)$ & $(128.42)$ & $(4,329.19)$ \\
Crimes against the Person & & & & \\
Violent crimes & 0.55 & 13.21 & 402.25 & $4,183.4$ \\
& $(0.81)$ & $(4.80)$ & $(36.90)$ & $(1,507.29)$ \\
Gender violence & 0.29 & 6.95 & 211.48 & $2,199.4$ \\
& $(0.56)$ & $(3.16)$ & $(37.31)$ & $(787.54)$ \\
Other Crimes & & & & \\
Against police & 0.11 & 2.63 & 79.96 & 831.6 \\
& $(0.41)$ & $(2.63)$ & $(19.18)$ & $(288.21)$ \\
Driving crimes & 0.41 & 9.75 & 296.85 & $3,087.2$ \\
& $(0.75)$ & $(5.23)$ & $(65.55)$ & $(1,425.48)$ \\
Drug related crimes & 0.15 & 3.56 & 108.40 & $1,127.4$ \\
& $(0.41)$ & $(2.09)$ & $(20.18)$ & $(438.09)$ \\
\hline
\end{tabular}


Table 3: FCB football matches 2007-2011.

\begin{tabular}{|lc|}
\hline Attendance & \# of matches in the sample \\
\hline$>80,000$ spectators & 36 \\
$>60,000$ and $<80,000$ spectators & 58 \\
$>40,000$ and $<60,000$ spectators & 24 \\
$<40,000$ spectators & 7 \\
\hline Home matches & 125 \\
Away matches & 130 \\
\hline Type of match & \\
\hline Spanish Domestic League & 169 \\
Spanish King's Cup & 32 \\
European Champions League & 50 \\
Spanish and International Super Cups & 4 \\
\hline
\end{tabular}

Note: In this period FCB played Real Madrid CF, its main rival, ten times (home and away). 
Table 4: Daily average number of reported crimes by typology and by type of match played.

\begin{tabular}{|rccc|}
\hline Crime type & No Match & Home Match & Away Match \\
\hline Property Crimes & & & \\
Robberies & 34.95 & 36.29 & 35.68 \\
Thefts & 288.02 & 310.96 & 303.68 \\
Criminal damage & 8.15 & 8.27 & 9.19 \\
Crimes Against the Person & & & \\
Violent crimes & 12.71 & 14.03 & 14.55 \\
Gender violence & 6.78 & 7.30 & 7.32 \\
Other Crimes & & & \\
Against police & 2.53 & 2.64 & 2.98 \\
Driving crimes & 9.43 & 10.61 & 11.95 \\
Drug related crimes & 3.62 & 3.15 & 3.58 \\
\hline
\end{tabular}


Table 5: FCB home matches attendance and crime in the city at time of the match.

\begin{tabular}{|c|c|c|c|c|c|c|c|c|}
\hline & $\begin{array}{c}\text { (1) } \\
\text { Robberies }\end{array}$ & $\begin{array}{c}\text { (2) } \\
\text { Thefts }\end{array}$ & $\begin{array}{c}(3) \\
\text { Criminal } \\
\text { damage }\end{array}$ & $\begin{array}{c}(4) \\
\text { Violent } \\
\text { crimes }\end{array}$ & $\begin{array}{c}(5) \\
\text { Gender } \\
\text { Violence }\end{array}$ & $\begin{array}{c}(6) \\
\text { Against } \\
\text { Police }\end{array}$ & $\begin{array}{c}(7) \\
\text { Driving } \\
\text { crimes }\end{array}$ & $\begin{array}{c}\text { (8) } \\
\text { Drugs }\end{array}$ \\
\hline Stadium attendance & $\begin{array}{c}0.997 \\
{[0.734]}\end{array}$ & $\begin{array}{c}1.001 \\
{[0.880]}\end{array}$ & $\begin{array}{c}1.009 \\
{[0.456]}\end{array}$ & $\begin{array}{c}0.999 \\
{[0.975]}\end{array}$ & $\begin{array}{c}1.006 \\
{[0.822]}\end{array}$ & $\begin{array}{c}0.956 \\
{[0.278]}\end{array}$ & $\begin{array}{c}1.013 \\
{[0.675]}\end{array}$ & $\begin{array}{c}1.020 \\
{[0.421]}\end{array}$ \\
\hline$>80,000$ & $\begin{array}{c}0.913 \\
{[0.174]}\end{array}$ & $\begin{array}{c}1.067 \\
{[0.188]}\end{array}$ & $\begin{array}{c}1.028 \\
{[0.761]}\end{array}$ & $\begin{array}{c}0.841 \\
{[0.271]}\end{array}$ & $\begin{array}{c}1.067 \\
{[0.692]}\end{array}$ & $\begin{array}{l}0.522 * \\
{[0.064]}\end{array}$ & $\begin{array}{c}0.833 \\
{[0.454]}\end{array}$ & $\begin{array}{c}1.134 \\
{[0.611]}\end{array}$ \\
\hline$>60,000$ & $\begin{array}{l}1.072 * \\
{[0.071]}\end{array}$ & $\begin{array}{c}1.037 \\
{[0.511]}\end{array}$ & $\begin{array}{c}1.084 \\
{[0.303]}\end{array}$ & $\begin{array}{c}1.181 \\
{[0.190]}\end{array}$ & $\begin{array}{c}0.964 \\
{[0.557]}\end{array}$ & $\begin{array}{c}0.993 \\
{[0.986]}\end{array}$ & $\begin{array}{c}1.040 \\
{[0.848]}\end{array}$ & $\begin{array}{c}1.116 \\
{[0.199]}\end{array}$ \\
\hline$>40,000$ & $\begin{array}{c}0.909 \\
{[0.319]}\end{array}$ & $\begin{array}{c}0.958 \\
{[0.358]}\end{array}$ & $\begin{array}{c}0.961 \\
{[0.598]}\end{array}$ & $\begin{array}{l}1.295^{*} \\
{[0.052]}\end{array}$ & $\begin{array}{c}1.066 \\
{[0.690]}\end{array}$ & $\begin{array}{c}0.469 \\
{[0.169]}\end{array}$ & $\begin{array}{c}0.902 \\
{[0.850]}\end{array}$ & $\begin{array}{c}0.632 \\
{[0.470]}\end{array}$ \\
\hline$>20,000$ & $\begin{array}{c}1.133 \\
{[0.277]}\end{array}$ & $\begin{array}{c}0.980 \\
{[0.631]}\end{array}$ & $\begin{array}{c}1.035 \\
{[0.803]}\end{array}$ & $\begin{array}{c}1.166 \\
{[0.555]}\end{array}$ & $\begin{array}{c}2.438 * * * \\
{[0.000]} \\
\end{array}$ & $\begin{array}{c}1.765 \\
{[0.470]}\end{array}$ & $\begin{array}{c}1.044 \\
{[0.864]}\end{array}$ & $\begin{array}{c}1.018 \\
{[0.983]}\end{array}$ \\
\hline Observations & 29,121 & 29,121 & 29,121 & 29,121 & 29,121 & 29,121 & 29,121 & 29,121 \\
\hline Climate controls & YES & YES & YES & YES & YES & YES & YES & YES \\
\hline Time controls & YES & YES & YES & YES & YES & YES & YES & YES \\
\hline Seasonal controls & YES & YES & YES & YES & YES & YES & YES & YES \\
\hline Monthly trends & YES & YES & YES & YES & YES & YES & YES & YES \\
\hline Yearly trends & YES & YES & YES & YES & YES & YES & YES & YES \\
\hline Lunar phase & YES & YES & YES & YES & YES & YES & YES & YES \\
\hline Holiday dummy & YES & YES & YES & YES & YES & YES & YES & YES \\
\hline Derby dummy & YES & YES & YES & YES & YES & YES & YES & YES \\
\hline Type of competition & YES & YES & YES & YES & YES & YES & YES & YES \\
\hline
\end{tabular}

Note: Attendance is expressed in 10,000. >80,000, for instance, is a dummy that takes the value of 1 for matches with an attendance above the specified threshold. The estimations for each level of attendance are performed separately. Climate controls include: average rainfall, average number of sun hours, average temperature, average pressure and average wind speed. Time controls include: hour of the day, day of the week, day of the month, day of the year, hour-by-weekday (2-hour window), week of the year, month and year. Seasonal controls include dummies for summer (mainly September) and winter. Type of competition includes dummies for: Spanish Domestic League, European Champions League, Spanish King's Cup and Super Cups (both Spanish and International). Robust standard errors used. p-values in square brackets. $* * * \mathrm{p}<0.01, * * \mathrm{p}<0.05, * \mathrm{p}<0.1$. 
Table 6: Control variables.

\begin{tabular}{|c|c|c|c|c|c|c|c|c|}
\hline & $\begin{array}{c}(1) \\
\text { Robberies }\end{array}$ & $\begin{array}{c}\text { (2) } \\
\text { Thefts }\end{array}$ & $\begin{array}{c}(3) \\
\text { Criminal } \\
\text { damage }\end{array}$ & $\begin{array}{c}(4) \\
\text { Violent } \\
\text { crimes }\end{array}$ & $\begin{array}{c}5) \\
\text { Gender } \\
\text { Violence }\end{array}$ & $\begin{array}{c}(6) \\
\text { Against } \\
\text { Police }\end{array}$ & $\begin{array}{c}(7) \\
\text { Driving } \\
\text { crimes }\end{array}$ & $\begin{array}{c}(8) \\
\text { Drugs }\end{array}$ \\
\hline Rainfall & $\begin{array}{l}0.998^{*} \\
{[0.080]}\end{array}$ & $\begin{array}{c}0.998 * * * \\
{[0.000]}\end{array}$ & $\begin{array}{l}1.002^{*} \\
{[0.057]}\end{array}$ & $\begin{array}{c}0.996 * * * \\
{[0.000]}\end{array}$ & $\begin{array}{c}0.999 \\
{[0.561]}\end{array}$ & $\begin{array}{c}0.999 \\
{[0.732]}\end{array}$ & $\begin{array}{l}0.997^{* * *} \\
{[0.028]}\end{array}$ & $\begin{array}{l}0.997 * \\
{[0.085]}\end{array}$ \\
\hline Sun hours & $\begin{array}{c}1.004 \\
{[0.118]}\end{array}$ & $\begin{array}{c}1.007 * * * \\
{[0.000]}\end{array}$ & $\begin{array}{c}1.007 * * * \\
{[0.001]}\end{array}$ & $\begin{array}{c}1.006 * * * \\
{[0.000]}\end{array}$ & $\begin{array}{l}0.994 * * \\
{[0.011]}\end{array}$ & $\begin{array}{c}1.009 \\
{[0.149]}\end{array}$ & $\begin{array}{c}1.000 \\
{[0.986]}\end{array}$ & $\begin{array}{c}0.998 \\
{[0.573]}\end{array}$ \\
\hline Temperature & $\begin{array}{c}1.009 * * * \\
{[0.000]}\end{array}$ & $\begin{array}{c}1.007 * * * \\
{[0.000]}\end{array}$ & $\begin{array}{c}0.999 \\
{[0.718]}\end{array}$ & $\begin{array}{c}1.012 * * * \\
{[0.000]}\end{array}$ & $\begin{array}{c}1.016 * * * \\
{[0.000]}\end{array}$ & $\begin{array}{c}1.001 \\
{[0.916]}\end{array}$ & $\begin{array}{c}1.023 * * * \\
{[0.000]}\end{array}$ & $\begin{array}{c}1.021 * * * \\
{[0.000]}\end{array}$ \\
\hline Pressure & $\begin{array}{l}1.000 * * \\
{[0.016]}\end{array}$ & $\begin{array}{l}1.000 * \\
{[0.057]}\end{array}$ & $\begin{array}{c}1.000 \\
{[0.401]}\end{array}$ & $\begin{array}{c}1.000 * * * \\
{[0.008]}\end{array}$ & $\begin{array}{l}1.000^{* *} \\
{[0.016]}\end{array}$ & $\begin{array}{c}1.000 \\
{[0.793]}\end{array}$ & $\begin{array}{c}1.000 \\
{[0.432]}\end{array}$ & $\begin{array}{c}1.000 \\
{[0.143]}\end{array}$ \\
\hline Wind speed & $\begin{array}{c}0.998 * * * \\
{[0.007]}\end{array}$ & $\begin{array}{c}0.999 * * * \\
{[0.000]}\end{array}$ & $\begin{array}{c}0.998 \\
{[0.174]}\end{array}$ & $\begin{array}{c}1.000 \\
{[0.923]}\end{array}$ & $\begin{array}{c}1.000 \\
{[0.899]}\end{array}$ & $\begin{array}{c}0.996 \\
{[0.340]}\end{array}$ & $\begin{array}{c}0.996 \\
{[0.114]}\end{array}$ & $\begin{array}{c}0.993 * * * \\
{[0.006]}\end{array}$ \\
\hline Summer dummy & $\begin{array}{c}0.529 * * * \\
{[0.000]}\end{array}$ & $\begin{array}{c}0.884 * * * \\
{[0.001]}\end{array}$ & $\begin{array}{c}1.067 \\
{[0.648]}\end{array}$ & $\begin{array}{c}1.505^{*} \\
{[0.0833]}\end{array}$ & $\begin{array}{l}1.935^{* *} \\
{[0.028]}\end{array}$ & $\begin{array}{c}1.122 \\
{[0.678]}\end{array}$ & $\begin{array}{c}0.725 \\
{[0.224]}\end{array}$ & $\begin{array}{c}2.103 * * * \\
{[0.009]}\end{array}$ \\
\hline Winter dummy & $\begin{array}{c}1.340 \\
{[0.171]}\end{array}$ & $\begin{array}{c}0.969 \\
{[0.637]}\end{array}$ & $\begin{array}{c}0.895 \\
{[0.291]}\end{array}$ & $\begin{array}{c}3.179 * * * \\
{[0.001]}\end{array}$ & $\begin{array}{l}0.456^{*} \\
{[0.072]}\end{array}$ & $\begin{array}{c}0.653 \\
{[0.482]}\end{array}$ & $\begin{array}{c}0.633 \\
{[0.257]}\end{array}$ & $\begin{array}{c}0.549 \\
{[0.357]}\end{array}$ \\
\hline Lunar phase & $\begin{array}{c}0.993 \\
{[0.890]}\end{array}$ & $\begin{array}{c}1.021 \\
{[0.223]}\end{array}$ & $\begin{array}{c}1.038 \\
{[0.282]}\end{array}$ & $\begin{array}{c}1.021 \\
{[0.731]}\end{array}$ & $\begin{array}{l}1.090 * * \\
{[0.010]}\end{array}$ & $\begin{array}{c}0.931 \\
{[0.663]}\end{array}$ & $\begin{array}{c}1.048 \\
{[0.461]}\end{array}$ & $\begin{array}{c}0.982 \\
{[0.876]}\end{array}$ \\
\hline Holiday dummy & $\begin{array}{c}0.999 \\
{[0.899]}\end{array}$ & $\begin{array}{l}0.984 * \\
{[0.066]}\end{array}$ & $\begin{array}{c}0.957 * * \\
{[0.026]}\end{array}$ & $\begin{array}{l}1.041 * * \\
{[0.033]}\end{array}$ & $\begin{array}{c}0.956 \\
{[0.404]}\end{array}$ & $\begin{array}{c}1.197 * * * \\
{[0.007]}\end{array}$ & $\begin{array}{c}0.967 \\
{[0.179]}\end{array}$ & $\begin{array}{c}1.140 \\
{[0.165]}\end{array}$ \\
\hline Derby dummy & $\begin{array}{c}0.793 \\
{[0.182]}\end{array}$ & $\begin{array}{c}1.017 \\
{[0.790]}\end{array}$ & $\begin{array}{c}1.084 \\
{[0.325]}\end{array}$ & $\begin{array}{c}1.710 \\
{[0.104]}\end{array}$ & $\begin{array}{l}1.626^{* *} \\
{[0.031]}\end{array}$ & $\begin{array}{c}1.841 * * \\
{[0.0 .028]}\end{array}$ & $\begin{array}{c}0.867 \\
{[0.790]}\end{array}$ & $\begin{array}{c}0.463 \\
{[0.347]}\end{array}$ \\
\hline King's Cup & $\begin{array}{c}0.789 \\
{[0.129]}\end{array}$ & $\begin{array}{l}1.060^{* * *} \\
{[0.015]}\end{array}$ & $\begin{array}{c}1.006 \\
{[0.953]}\end{array}$ & $\begin{array}{c}0.655^{* *} \\
{[0.020]}\end{array}$ & $\begin{array}{c}0.851 \\
{[0.378]}\end{array}$ & $\begin{array}{c}0.397 \\
{[0.266]}\end{array}$ & $\begin{array}{c}0.895 \\
{[0.627]}\end{array}$ & $\begin{array}{c}0.170 \\
{[0.119]}\end{array}$ \\
\hline Champions League & $\begin{array}{c}0.989 \\
{[0.791]}\end{array}$ & $\begin{array}{l}0.939 * \\
{[0.061]}\end{array}$ & $\begin{array}{c}1.073 \\
{[0.617]}\end{array}$ & $\begin{array}{c}0.808 \\
{[0.418]}\end{array}$ & $\begin{array}{l}0.658^{*} \\
{[0.087]}\end{array}$ & $\begin{array}{c}1.014 \\
{[0.952]}\end{array}$ & $\begin{array}{c}0.626 \\
{[0.119]}\end{array}$ & $\begin{array}{l}0.603 * \\
{[0.055]}\end{array}$ \\
\hline Domestic League & $\begin{array}{c}0.924 * * * \\
{[0.006]}\end{array}$ & $\begin{array}{c}0.965 \\
{[0.334]}\end{array}$ & $\begin{array}{c}0.978 \\
{[0.548]}\end{array}$ & $\begin{array}{c}0.947 \\
{[0.724]}\end{array}$ & $\begin{array}{c}0.828 \\
{[0.349]}\end{array}$ & $\begin{array}{c}1.149 \\
{[0.487]}\end{array}$ & $\begin{array}{c}0.962 \\
{[0.734]}\end{array}$ & $\begin{array}{c}1.017 \\
{[0.884]}\end{array}$ \\
\hline Super Cups & $\begin{array}{c}1.077 \\
{[0.812]}\end{array}$ & $\begin{array}{c}0.955 \\
{[0.815]}\end{array}$ & $\begin{array}{c}0.834 \\
{[0.469]}\end{array}$ & $\begin{array}{c}1.352 \\
{[0.372]}\end{array}$ & $\begin{array}{c}4.2 \mathrm{e}-08 * * * \\
{[0.000]}\end{array}$ & $\begin{array}{c}3.221 \\
{[0.287]}\end{array}$ & $\begin{array}{c}3.7 \mathrm{e}-09 * * * \\
{[0.000]}\end{array}$ & $\begin{array}{c}2.249 \\
{[0.126]}\end{array}$ \\
\hline Observations & 29,121 & 29,121 & 29,121 & 29,121 & 29,121 & 29,121 & 29,121 & 29,121 \\
\hline Hour of the day & YES & YES & YES & YES & YES & YES & YES & YES \\
\hline Hour-by-weekday (2) & YES & YES & YES & YES & YES & YES & YES & YES \\
\hline Day of the week & YES & YES & YES & YES & YES & YES & YES & YES \\
\hline Day of the month & YES & YES & YES & YES & YES & YES & YES & YES \\
\hline Day of the year & YES & YES & YES & YES & YES & YES & YES & YES \\
\hline Week of the year & YES & YES & YES & YES & YES & YES & YES & YES \\
\hline Month of the year & YES & YES & YES & YES & YES & YES & YES & YES \\
\hline Year & YES & YES & YES & YES & YES & YES & YES & YES \\
\hline
\end{tabular}

Note: Robust standard errors used. p-values in square brackets. $* * * p<0.01, * * p<0.05,{ }^{*} p<0.1$. 
Figure 4: Hours prior to and after FCB home matches.

Panel 4a: Robberies

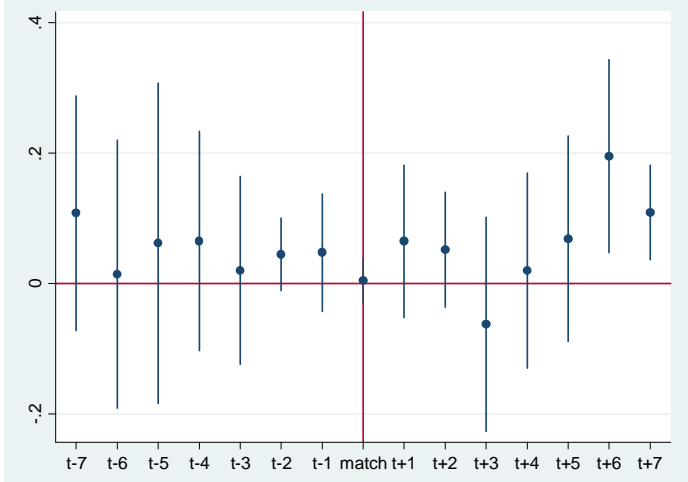

Panel 4c: Criminal damage

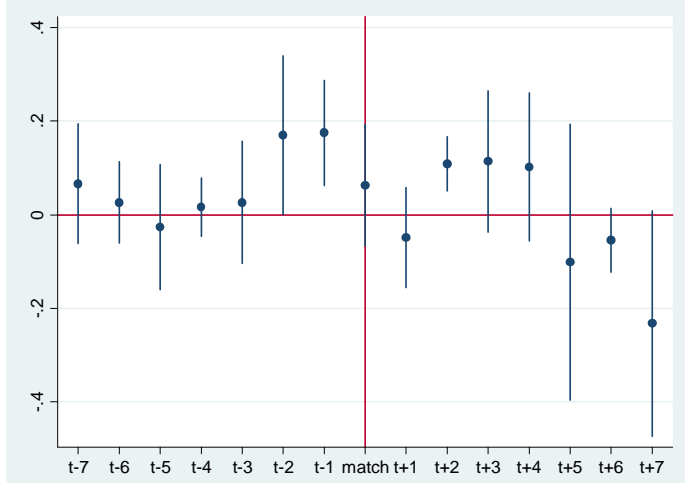

Panel 4e: Gender violence

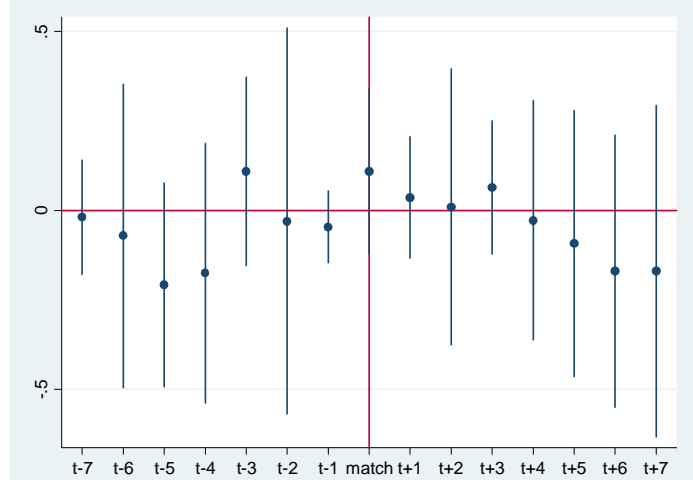

Panel 4g: Driving crimes

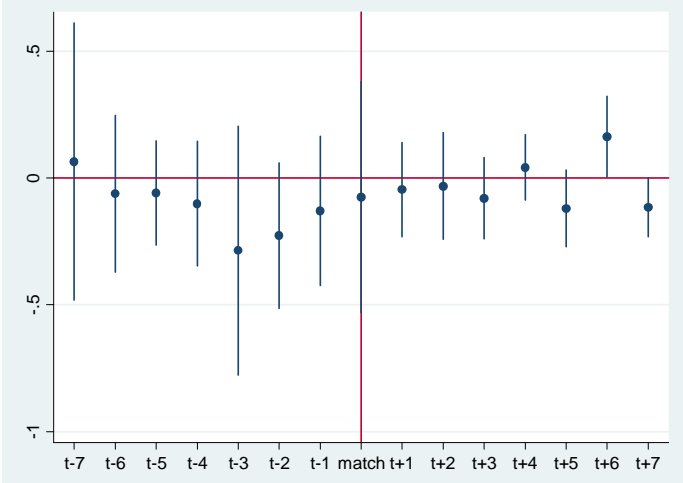

Panel 4b: Thefts

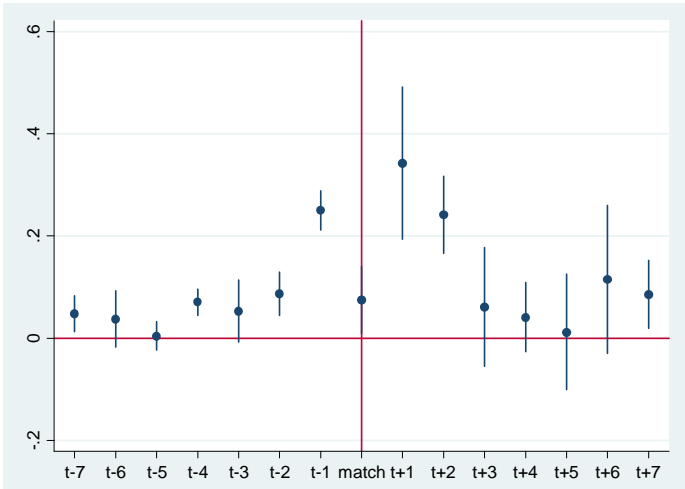

Panel 4d: Violent crimes

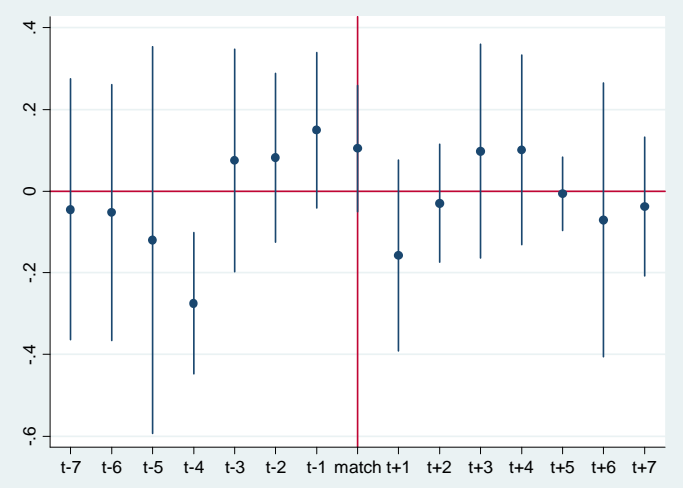

Panel 4f: Against police

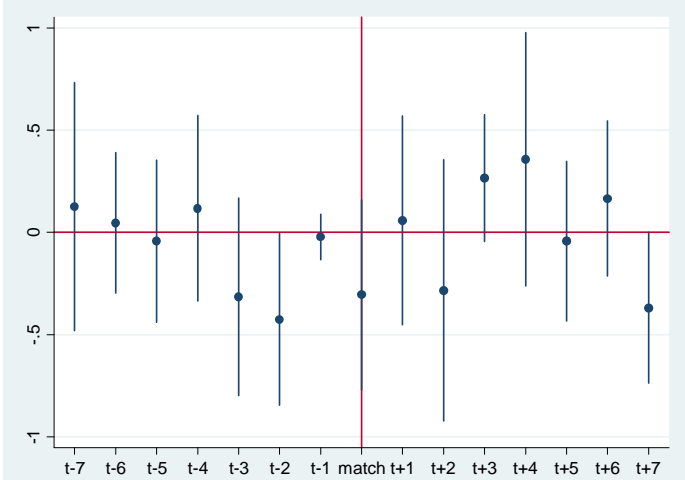

Panel 4h: Drug related crimes

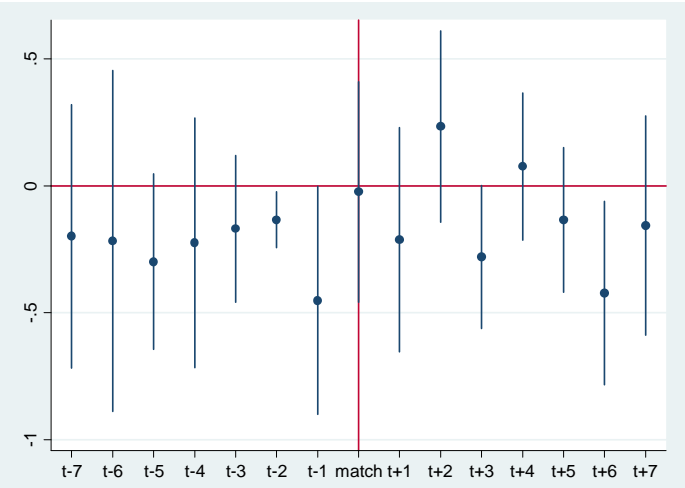


Table 7: FCB away matches and crime in the city during the game.

\begin{tabular}{lcccccccc}
\hline & $(1)$ & $(2)$ & $(3)$ & $(4)$ & $(5)$ & $(6)$ & $(7)$ & $(8)$ \\
& Robberies & Thefts & $\begin{array}{c}\text { Criminal } \\
\text { damage }\end{array}$ & $\begin{array}{c}\text { Violent } \\
\text { crimes }\end{array}$ & $\begin{array}{c}\text { Gender } \\
\text { violence }\end{array}$ & $\begin{array}{c}\text { Against } \\
\text { police }\end{array}$ & $\begin{array}{c}\text { Driving } \\
\text { crimes }\end{array}$ & Drugs \\
\hline Away match & 0.985 & 0.979 & 1.016 & 1.055 & 0.824 & $1.574 * * *$ & 0.950 & $0.629^{* * *}$ \\
& {$[0.805]$} & {$[0.525]$} & {$[0.643]$} & {$[0.226]$} & {$[0.240]$} & {$[0.000]$} & {$[0.559]$} & {$[0.001]$} \\
\hline Observations & 29,121 & 29,121 & 29,121 & 29,121 & 29,121 & 29,121 & 29,121 & 29,121 \\
Climate controls & YES & YES & YES & YES & YES & YES & YES & YES \\
Time controls & YES & YES & YES & YES & YES & YES & YES & YES \\
Seasonal controls & YES & YES & YES & YES & YES & YES & YES & YES \\
Monthly trends & YES & YES & YES & YES & YES & YES & YES & YES \\
Yearly trends & YES & YES & YES & YES & YES & YES & YES & YES \\
Lunar phase & YES & YES & YES & YES & YES & YES & YES & YES \\
Holiday dummy & YES & YES & YES & YES & YES & YES & YES & YES \\
Derby dummy & YES & YES & YES & YES & YES & YES & YES & YES \\
Type of competition & YES & YES & YES & YES & YES & YES & YES & YES \\
\hline
\end{tabular}

Note: Climate controls include: average rainfall, average number of sun hours, average temperature, average pressure and average wind speed. Time controls include: hour of the day, day of the week, day of the month, day of the year, hour-by-weekday (2-hour window), week of the year, month and year. Seasonal controls include dummies for summer (mainly September) and winter. Type of competition includes dummies for: Spanish Domestic League, European Champions League, Spanish King's Cup and Super Cups (both Spanish and International). Robust standard errors used. p-values in square brackets. $* * * \mathrm{p}<0.01, * * \mathrm{p}<0.05, * \mathrm{p}<0.1$. 
Figure 5. Hours prior to and after FCB away matches.

Panel 5a: Robberies

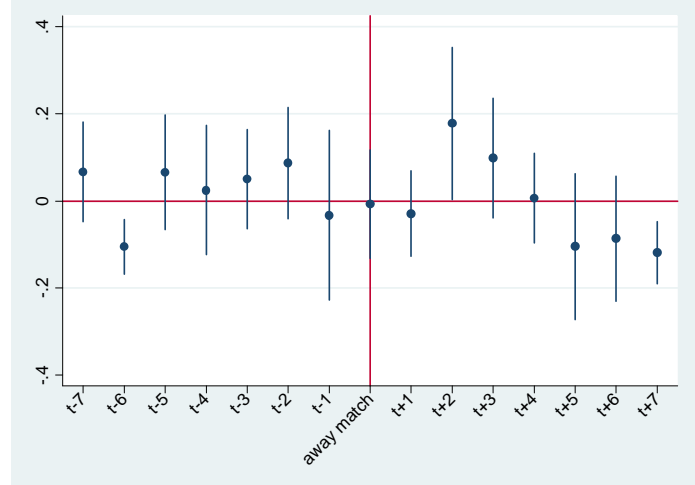

Panel 5c: Criminal damage

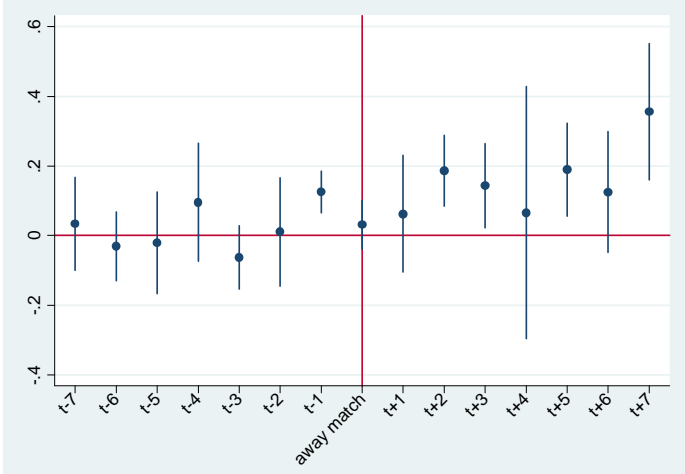

Panel 5e: Gender violence

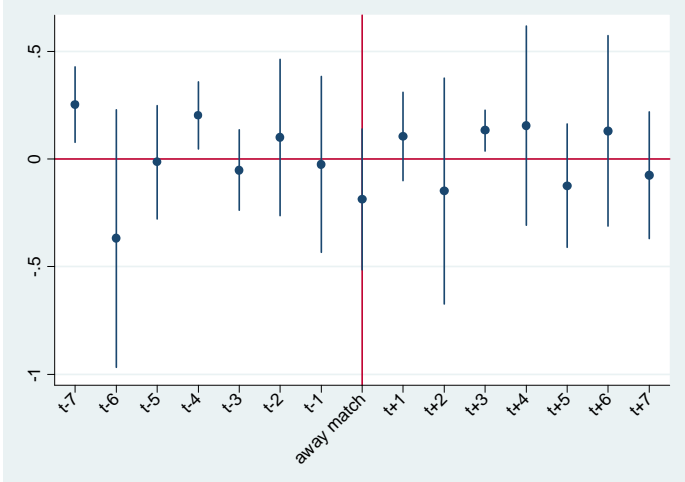

Panel 5g: Driving crimes

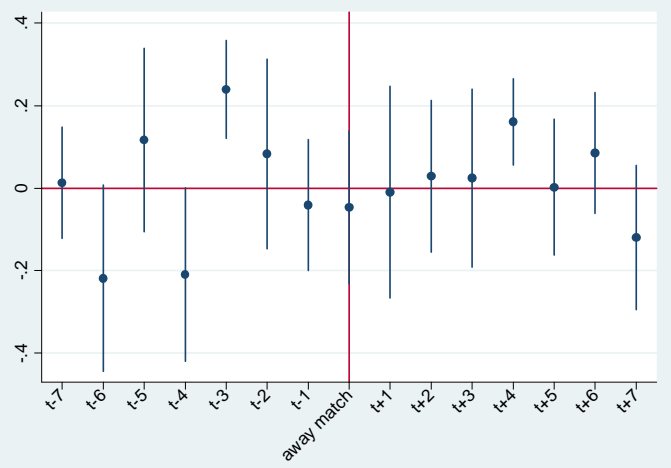

Panel 5b: Thefts

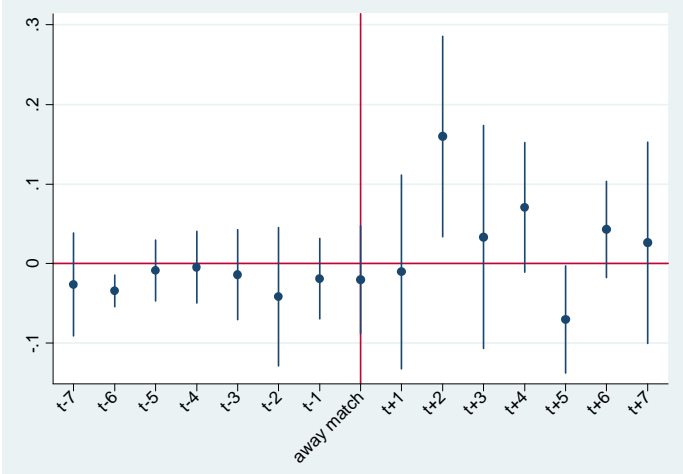

\section{Panel 5d: Violent crimes}

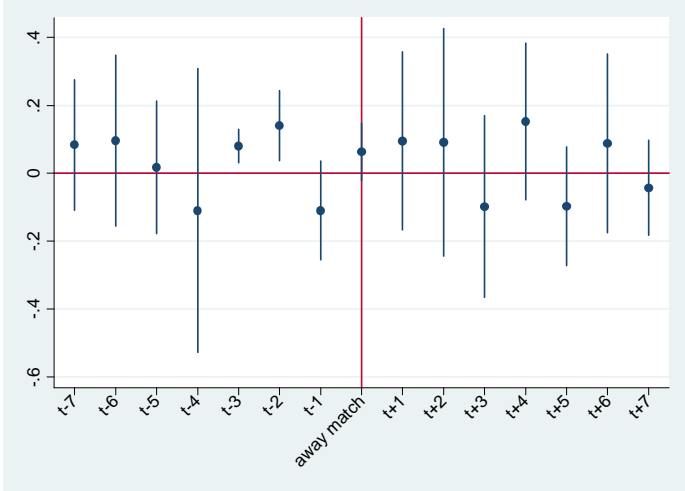

Panel 5f: Against police

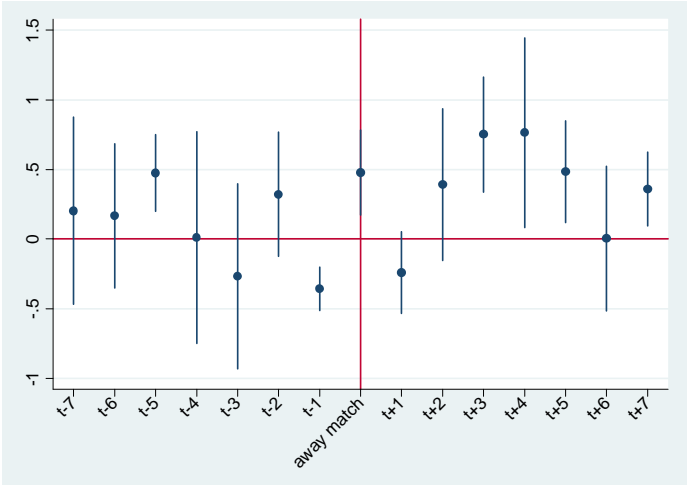

Panel 5h: Drug related crimes

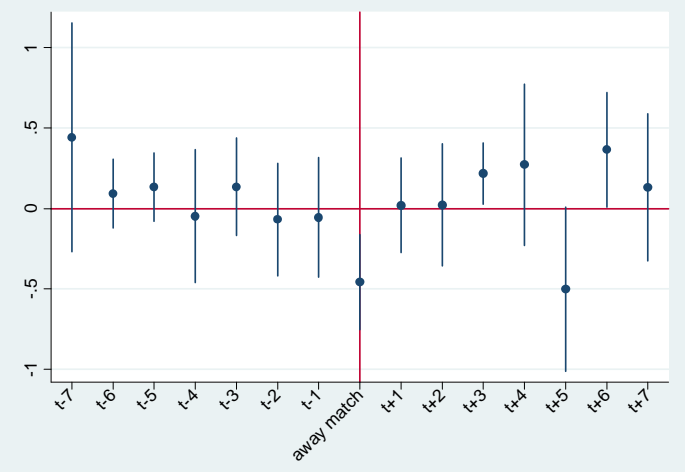


Table 8: Psychological effects of a FCB defeat.

\begin{tabular}{lccc|ccc}
\hline & \multicolumn{3}{c}{ Violent crimes } & \multicolumn{3}{c}{ Gender violence } \\
\hline $\mathrm{T}+1$ & Lost & Lost home & $\begin{array}{c}\text { Lost/Draw } \\
\text { home }\end{array}$ & Lost & Lost home & $\begin{array}{c}\text { Lost/Draw } \\
\text { home }\end{array}$ \\
& 1.260 & 0.905 & 1.309 & 1.222 & 0.750 & 1.009 \\
$\mathrm{~T}+2$ & {$[0.436]$} & {$[0.777]$} & {$[0.132]$} & {$[0.296]$} & {$[0.155]$} & {$[0.928]$} \\
& 1.249 & 1.314 & 1.017 & 0.813 & $0.221^{*}$ & 0.654 \\
$\mathrm{~T}+3$ & {$[0.447]$} & {$[0.539]$} & {$[0.919]$} & {$[0.447]$} & {$[0.086]$} & {$[0.118]$} \\
& 0.937 & 1.055 & 1.066 & 1.497 & 2.465 & 1.512 \\
$\mathrm{~T}+4$ & {$[0.743]$} & {$[0.888]$} & {$[0.814]$} & {$[0.337]$} & {$[0.152]$} & {$[0.121]$} \\
& 0.688 & 0.877 & 1.164 & 1.575 & $1.921^{*}$ & 1.270 \\
$\mathrm{~T}+5$ & {$[0.193]$} & {$[0.821]$} & {$[0.317]$} & {$[0.156]$} & {$[0.090]$} & {$[0.582]$} \\
& 1.083 & $1.963 * *$ & 1.322 & 0.889 & $1.823^{*}$ & 1.464 \\
$\mathrm{~T}+6$ & {$[0.781]$} & {$[0.023]$} & {$[0.105]$} & {$[0.786]$} & {$[0.091]$} & {$[0.281]$} \\
& 0.919 & 1.046 & $0.760 *$ & 0.904 & $1.986^{*}$ & $1.760^{* *}$ \\
$\mathrm{~T}+7$ & {$[0.571]$} & {$[0.837]$} & {$[0.065]$} & {$[0.628]$} & {$[0.054]$} & {$[0.032]$} \\
& 1.260 & 0.905 & 1.309 & 1.222 & 0.750 & 1.009 \\
& {$[0.436]$} & {$[0.777]$} & {$[0.132]$} & {$[0.296]$} & {$[0.155]$} & {$[0.928]$} \\
\hline Observations & 29,121 & 29,121 & 29,121 & 29,121 & 29,121 & 29,121 \\
Climate controls & YES & YES & YES & YES & YES & YES \\
Time controls & YES & YES & YES & YES & YES & YES \\
Seasonal controls & YES & YES & YES & YES & YES & YES \\
Monthly trends & YES & YES & YES & YES & YES & YES \\
Yearly trends & YES & YES & YES & YES & YES & YES \\
Lunar phase & YES & YES & YES & YES & YES & YES \\
Holiday dummy & YES & YES & YES & YES & YES & YES \\
Derby dummy & YES & YES & YES & YES & YES & YES \\
Type of competition & YES & YES & YES & YES & YES & YES \\
\hline
\end{tabular}

Note: see notes to Table 7. 